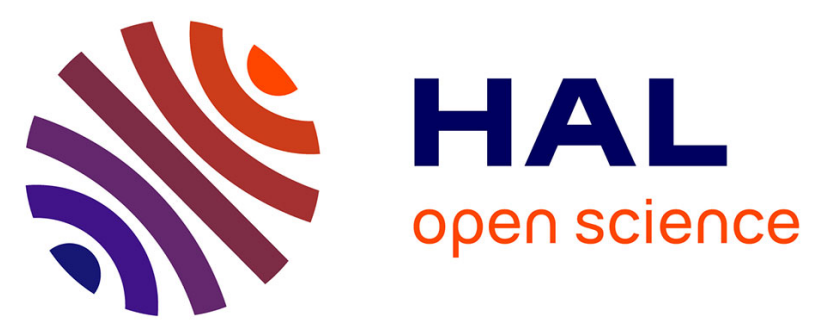

\title{
Differential sensitivity of metabolically competent and non-competent HepaRG cells to apoptosis induced by diclofenac combined or not with TNF-alpha
}

Houssein Al-Attrache, Ahmad Sharanek, Audrey Burban, Matthew Burbank, Thomas Gicquel, Ziad Abdel-Razzak, Christiane Guguen-Guillouzo, Isabelle Morel, André Guillouzo

\section{To cite this version:}

Houssein Al-Attrache, Ahmad Sharanek, Audrey Burban, Matthew Burbank, Thomas Gicquel, et al.. Differential sensitivity of metabolically competent and non-competent HepaRG cells to apoptosis induced by diclofenac combined or not with TNF-alpha. Toxicology Letters, 2016, 258, pp.71-86. 10.1016/j.toxlet.2016.06.008 . hal-01372855

\section{HAL Id: hal-01372855}

\section{https://hal-univ-rennes1.archives-ouvertes.fr/hal-01372855}

Submitted on 14 Oct 2016

HAL is a multi-disciplinary open access archive for the deposit and dissemination of scientific research documents, whether they are published or not. The documents may come from teaching and research institutions in France or abroad, or from public or private research centers.
L'archive ouverte pluridisciplinaire HAL, est destinée au dépôt et à la diffusion de documents scientifiques de niveau recherche, publiés ou non, émanant des établissements d'enseignement et de recherche français ou étrangers, des laboratoires publics ou privés. 


\section{Differential sensitivity of metabolically competent and non-competent HepaRG cells to apoptosis induced by diclofenac combined or not with TNF-a}

Houssein Al-Attrache a, b, d, Ahmad Sharanek a, b, Audrey Burban a, b, Matthew Burbank a, b, Thomas

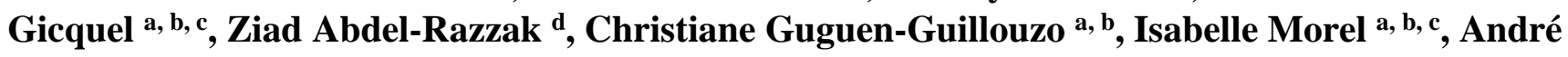
Guillouzo a, b

a Inserm U991, Faculty of Pharmacy, Rennes, France ${ }^{\mathrm{b}}$ Rennes 1 University, Rennes, France ${ }^{\mathrm{c}}$ Laboratory Emergency and Intensive Care, Hospital Pontchaillou, Rennes, France ${ }^{\mathrm{d}}$ Laboratory of Applied Biotechnology: biomolecules, biotherapy and bioprocesses (LBA3B), AZM Center-Tripoli and EDST-PRASE-Beirut, Rafic Hariri Campus_-Lebanese University, Lebanon 


\section{HIGHLIGHTS}

- HepaRG hepatocytes are less sensitive to DCF than HepG2 cells and undifferentiated HepaRG cells

- The lower sensitivity of HepaRG hepatocytes is related to their high detoxifying capacity

- Inhibition of glutathione transferases results in increased DCF cytotoxicity

- TNF- $\alpha$ potentiation of DCF cytotoxicity is not observed in undifferentiated HepaRG cells

- DCF-induced cholestasis typified by bile canaliculi dilatation is not aggravated by TNF- $\alpha$ 


\section{Abstract}

The role of reactive metabolites and inflammatory stress has been largely evoked in idiosyncratic hepatotoxicity of diclofenac (DCF); however mechanisms remain poorly understood. We aimed to evaluate the influence of liver cell phenotype on the hepatotoxicity of DCFcombined or not with TNF-a using differentiated and undifferentiated HepaRG cells, and for comparison, HepG2 cells. Our results demonstrate that after a 24h-treatment metabolizing HepaRG cells were less sensitive to DCF than their undifferentiated non-metabolizing counterparts as shown by lower oxidative and endoplasmic reticulum stress responses and lower activation of caspase 9. Differentiated HepaRG cells were also less sensitive than HepG2 cells. Their lower sensitivity to DCF was related to their high content in glutathione transferases. DCFinduced apoptotic effects were potentiated by TNF- $\alpha$ only in death receptor-expressing differentiated HepaRG and HepG2 cells and were associated with marked activation of caspase 8. TNF- $\alpha$ co-treatment did not aggravate DCF-induced cholestatic features. Altogether, our results demonstrate that (i) lower sensitivity to DCF of differentiated HepaRG cells compared to their non-metabolically active counterparts was related to their high detoxifying capacity, giving support to the higher sensitivity of nonhepatic tissues than liver to this drug; (ii) TNF-a-potentiation of DCF cytotoxicity occurred only in death receptor-expressing cells. 


\section{Abbreviations:}

ABT, 1-Aminobenzotriazole; Ac-DEVD-AMC, N-Acetyl-Asp-Glu-Val-Asp-7-amido-4methylcoumarin; AC-IETD-AMC, Ac-lle-Glu-Thr-Asp-7-Amino-4-methylcoumarin; ACLEHD-AMC, Ac-Leu-Glu-His-Asp-7-Amino-4-methylcoumarin; BSEP, bile salt export pump; CDF, 5 (and 6)-carboxy-2',7'-dichlorofluorescein (CDF); CRP, C-reactive protein; CYP450, cytochrome P450; DCF, diclofenac; DILI, drug-induced liver injury; ER, endoplasmic reticulum; H2-DCFDA, 2',7'-dichlorodihydrofluorescein; HO1, heme oxygenase 1; IL-8, interleukin-8; MnSOD, manganese superoxide dismutase; MRP2, multidrug associated protein 2; MTT, methylthiazoltetrazolium; NAC, N-acetyl cysteine; NTCP, $\mathrm{Na}^{+}$-dependent taurocholate cotransporting polypeptide; PBS, phosphate buffered saline; ROS, reactive oxygen species; RT-qPCR, real-time quantitative polymerase chain reaction; TNF- $\alpha$, tumor necrosis factor $\alpha$.

Keywords: Drug metabolism, differentiation status, tumor necrosis factor $\alpha$, caspases, reactive oxygen species, endoplasmic reticulum stress, cholestasis, glutathione transferases, HepG2 cells, primary human hepatocytes. 


\section{Introduction}

Drug-induced idiosyncratic hepatotoxicity represents $13-17 \%$ of all cases of acute liver failure (Bjornsson and Olsson, 2006). Formation of reactive metabolites, generation of oxidative stress, inflammatory stress and immune response are recognized to be potential critical determinants (Uetrecht, 2006).

Diclofenac $(\mathrm{DCF})$ is a non-steroidal anti-inflammatory drug widely used for the treatment of rheumatoid arthritis, osteoarthritis and acute injury pain. Its administration has been associated with adverse effects in various organs, especially the gastrointestinal tract and kidney. DCF has also caused rare cases of hepatocellular injury, cholestasis or mixed hepatocellular injury and cholestasis (Banks et al., 1995; Breen et al., 1986; Watanabe et al., 2007). DCF-induced liver toxicity has been related to the formation of reactive metabolites, i.e. quinone imines from 4'-OH-DCF and 5OH-DCF, and acyl glucuronides primarily catalyzed by UGT2B7 (Bort et al., 1999; Kretz-Rommel and Boelsterli, 1993; Wang et al., 2004). DCF-acyl glucuronides can bind selective proteins, including dipeptidyl peptidase IV, a canalicular membrane protein (Seitz and Boelsterli, 1998; Seitz et al., 1998). However, the role of these protein adducts in the pathogenesis of DCF-associated liver toxicity remains unclear (Aithal and Day, 2007; Banks et al., 1995).

DCF and its CYP-mediated metabolites 4'-OH-DCF and 5-OH-DCF induce concentration-dependent apoptosis at equimolar concentrations, the greatest proapoptotic activity being produced by $5-\mathrm{OH}-\mathrm{DCF}$ in primary human hepatocytes (Bort et al., 1999). However, DCF does not appear to be more cytotoxic to human hepatocytes than to HepG2 cells which usually express low drug metabolizing enzyme activities (Fredriksson et al., 2011; Gomez-Lechon et al., 2003b). Moreover, DCF has been 
shown to be toxic to non-hepatic organs and cells at doses even lower than those required for liver toxicity ( $\mathrm{Ng}$ et al., 2008). All these data make questionable the direct involvement of CYP-derived metabolites in DCF cytotoxicity in vivo and in vitro. DCFinduced apoptosis is strongly potentiated by TNF- $\alpha$ in HepG2 cells (Fredriksson et al., 2011; Maiuri et al., 2015) and lipopolysaccharide in rodent liver (Deng et al., 2006). The involvement of the intrinsic apoptotic pathway characterized by disruption of mitochondrial integrity has been demonstrated in various studies (Fredriksson et al., 2011; Gomez-Lechon et al., 2003a), and oxidative and endoplasmic reticulum (ER) stresses have been identified as independent cytotoxic responses to both DCF alone and the combination DCF/TNF- $\alpha$ (Fredriksson et al., 2014). The synergistic effect of DCF/TNF- $\alpha$ co-treatment appeared to occur mostly via activation of the extrinsic apoptotic pathway (Fredriksson et al., 2011).

In the present work, we further investigated mechanisms of DCF hepatotoxicity and cross-talk between hepatocyte apoptosis induced by DCF and TNF- $\alpha$ challenge using differentiated, metabolically competent and undifferentiated, non metabolically competent HepaRG cells and for comparison, HepG2 cells. At their undifferentiated stage HepaRG cells express markers of progenitors and do not exhibit detectable drug metabolizing enzyme activities; however, they can reach the capacity to express functions of mature hepatocytes, including CYP2C9 and CYP3A4 which are the main CYPs involved in the formation of CYP-mediated metabolites of DCF (Aninat et al., 2006; Guillouzo and Guguen-Guillouzo, 2008), as well as detoxifying enzymes (Aninat et al., 2006; Gerets et al., 2012; Rogue et al., 2012). We show here that sensitivity of liver cells to DCF-induced apoptosis was related to their phenotype and that potentiation by TNF- $\alpha$ was observed only in differentiated HepaRG cells expressing liver-specific functions and in HepG2 cells. 


\section{Materials and Methods}

\subsection{Chemicals and reagents}

1-Aminobenzotriazole (ABT), diclofenac sodium salt (DCF), dithiothreitol (DTT), methylthiazoltetrazolium $\quad$ (MTT), N-acetyl-Asp-Glu-Val-Asp-7-amido-4methylcoumarin (AC-DEVD-AMC), N-acetyl-cysteine (NAC), ethacrynic acid, 6 $\beta$ hydroxy-testosterone and testosterone were purchased from Sigma Aldrich (St. Quentin Fallavier, France). 2', 7'-Dichlorodihydrofluorescein (H2-DCFDA) was from Invitrogen Molecular Probe (Cergy-Pontoise, France). Ac-Ile-Glu-Thr-Asp-7-Amino-4methylcoumarin (AC-IETD-AMC) and Ac-Leu-Glu-His-Asp-7-Amino-4methylcoumarin (AC-LEHD-AMC) were supplied by Enzo Life Sciences (Lyon, France). TNF- $\alpha$ was provided by Promocell (Nuremberg, Germany). elF2 $\alpha$ (catalog 9722) and phospho-elF2 $\alpha$ (Ser51) (catalog 3597) were from Cell Signaling Technology (Danvers, MA, USA). CXCL8/IL-8 and Human C-reactive protein (CRP) DuoSet kits were from R\&D (Abingdon, United Kingdom). N-benzyloxycarbonyl-Leu-Glu(OMe)His-Asp(OMe)-fluoromethyl ketone (z-LEHD-fmk) was purchased from BD Biosciences (Le Pont de Claix, France) and etanercept was from Amgen (Thousand Oaks, CA, USA). Glutathione transferases (GST) A1/2 and M1/2 antibodies were gifts from Dr Caroline Aninat (Rennes).

\subsection{Cell cultures and treatments}

\subsubsection{Cell cultures}

HepaRG cells were seeded at a density of $2.6 \times 10^{4}$ cells $/ \mathrm{cm}^{2}$ in Williams' E medium supplemented with $10 \%$ Hyclone ${ }^{\circledR}$ fetal bovine serum (Thermo scientific, San Jose, USA), $100 \mathrm{U} / \mathrm{mL}$ penicillin, $100 \mu \mathrm{g} / \mathrm{mL}$ streptomycin, $5 \mu \mathrm{g} / \mathrm{mL}$ insulin, $2 \mathrm{mM}$ glutamine, and $50 \mu \mathrm{M}$ hydrocortisone hemisuccinate. After 2 weeks, these undifferentiated cells 
were shifted to the same medium supplemented with $1.7 \%$ dimethyl sulfoxide (DMSO) for further 2 weeks in order to obtain cells expressing liver-specific functions. At that time, cultures contained hepatocyte-like and progenitors/primitive biliary-like cells in nearly equal proportions (Cerec et al., 2007).

HepG2 cells were seeded at a density of $2.6 \times 10^{4} \mathrm{cells} / \mathrm{cm}^{2}$ in minimum essential medium- $\alpha$ supplemented with $10 \%$ Hyclone ${ }^{\circledR}$ fetal bovine serum, non-essential amino acids, $100 \mathrm{U} / \mathrm{ml}$ penicillin and $100 \mu \mathrm{g} / \mathrm{ml}$ streptomycin, and were used at subconfluence.

Primary human hepatocytes were obtained from Biopredic International (St Grégoire, France). They were isolated by collagenase-perfusion of liver biopsies from adult donors (Guguen-Guillouzo et al., 1982). These cells were cultured at a density of 1.5.10 $/ \mathrm{cm}^{2}$ in a Williams' E medium containing $10 \%$ Hyclone $₫$ fetal bovine serum without hydrocortisone hemisuccinate for the first $24 \mathrm{~h}$ and in a medium deprived of serum and hydrocortisone thereafter. Cultures were used at day 4.

\subsubsection{Treatments}

All treatments were performed on cells maintained in a medium containing $2 \%$ Hyclone ${ }^{\circledR}$ fetal bovine serum and $0.2 \%$ DMSO (used as a vehicle). Selection of TNFa concentration (10ng/ml) was based on previous studies (Bachour-El Azzi et al., 2014; Fredriksson et al., 2014) and preliminary experiments on determination of caspase 3 activity and CRP secretion levels. However, except otherwise indicated a co-treatment with DCF and cytokine meant a pre-treatment with the cytokine alone before treatment with DCF/cytokine combination.

\subsection{MTT assay}


Cytotoxicity was evaluated using the MTT colorimetric assay. Briefly, cells were seeded in 24-well plates and treated with either TNF- $\alpha$ or various concentrations of DCF $(50,100,150,200,250,350$ or $500 \mu M)$ after pre-treatment or not with TNF- $\alpha$. After medium removal, $500 \mu \mathrm{l}$ of serum-free medium containing MTT $(0.5 \mathrm{mg} / \mathrm{ml})$ was added to each well and incubated for $2 \mathrm{~h}$ at $37^{\circ} \mathrm{C}$. The water-insoluble formazan was

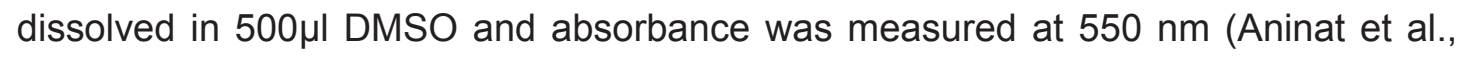
2006).

\subsection{Phase-contrast imaging analysis}

Cells were treated with DCF, TNF- $\alpha$ and DCF \pm TNF- $\alpha$ for different times $(0,4$ and 24h) and images were taken using a phase-contrast microscope (Inverted microscope Zeiss axiovert 200M and Axiocam MRm).

\subsection{ELISA assays}

C-reactive protein (CRP) and interleukin-8 (IL-8) proteins were measured in cell supernatants using CRP and CXCL8/IL-8 DuoSet kits, according to manufacturer's instructions. Briefly, supernatants were collected after $24 \mathrm{~h}$ treatment and stored at $80^{\circ} \mathrm{C}$ until analysis; 96-well microplates were coated with capture antibody and incubated overnight. Samples and standards were diluted appropriately and added for $2 \mathrm{~h}$ after a saturation step. Secondary antibody was added for $2 \mathrm{~h}$ after washing. Streptavidin-horseradish peroxidase and its substrate were used for the revelation step. Optical density was read at $450 \mathrm{~nm}$ with wavelength correction. All steps were performed at room temperature (Bachour-El Azzi et al., 2014).

\subsection{Determination of ROS generation}


ROS generation was determined by the $\mathrm{H}_{2}$-DCFDA assay. After treatment with DCF \pm TNF- $\alpha$ for $30 \mathrm{~min}, 2 \mathrm{~h}, 4 \mathrm{~h}, 8 \mathrm{~h}$ and $24 \mathrm{~h}, 10^{6}$ cells were incubated for $2 \mathrm{~h}$ at $37^{\circ} \mathrm{C}$ with $2 \mu \mathrm{M}$ $\mathrm{H}_{2}$-DCFDA and then washed with cold PBS, and scraped in potassium buffer (10mM, $\mathrm{pH} 7.4) /$ methanol (v/v) complemented with Triton X-100 (0.1\%). Fluorescence intensity of cell lysates was determined by spectrofluorimetry using excitation/emission wavelengths of 498/520 nm (Sharanek et al., 2014).

\subsection{Determination of caspase 3, 8 and 9 activities}

After treatment with DCF $\pm T N F-\alpha$, the cells were scraped in the culture medium, then centrifuged, washed with PBS, dried and stored at $-80^{\circ} \mathrm{C}$. Cell lysates were resuspended in $70 \mu \mathrm{l}$ of 4-(2-hydroxyethyl)-1-piperazine ethane sulfonic acid supplemented with anti-phosphatase and anti-protease. Then, $40 \mu \mathrm{g}$ proteins of each sample was placed in an opaque plate in triplicate and supplemented with caspase buffer (20 mM piperazine-1,4-bis-2-ethanesulfonic acid, pH 7.2, $100 \mathrm{mM} \mathrm{NaCl}, 10 \mathrm{mM}$ dithiotreitol, 1mM EDTA, 0.1\% 3-[(3-cholamidopropyl)dimethylammonio]-1-propane sulfonic acid and $10 \%$ sucrose. Then $2 \mu$ of DEVD-AMC, LEHD or IETD substrates for caspases 3, 9 and 8 respectively, was added. Fluorescence was measured at a wavelength between 380 and $420 \mathrm{~nm}$ for caspase 3 and between 405 and $465 \mathrm{~nm}$ for caspases 8 and 9 (Dumont et al., 2010; Maianski et al., 2004).

The influence of different inhibitors on caspase activities was also tested. The antioxidant $\mathrm{N}$-acetyl cysteine (NAC) was added to cultures treated with DCF, TNF- $\alpha$ or their combination for $24 \mathrm{~h}$ at the concentration of $5 \mathrm{mM}$ (Fredriksson et al., 2011; Sharanek et al., 2014; Son et al., 2013). Etanercept, a soluble p75 TNF-a receptor that prevents TNF- $\alpha$ to activate its membrane-bound receptor, thereby leading to inhibition of caspase 8 activation via the extrinsic apoptotic pathway (Jouan-Lanhouet et al., 
2012), and Z-LEHD-fmk, a specific inhibitor of caspase 9 activation (Maccarrone et al., 2000 ), were added at the concentrations of $10 \mu \mathrm{g} / \mathrm{ml}$ and $20 \mu \mathrm{M}$ respectively, one hour before treatment with DCF and/or TNF- $\alpha$.

\subsection{Western blotting analysis}

HepaRG cells were incubated in a medium added or not with DCF \pm TNF- $\alpha$ for $2 \mathrm{~h}$ after pre-treatment or not with the cytokine. P-elF2 $\alpha$, elF2 $\alpha$, GSTA1/2 and GSTM1/2 were analyzed according to methods previously described (Fredriksson et al., 2011; Zeng et al., 2014).

Briefly, after treatment, cells were washed with cold PBS and re-suspended in cell lysis buffer and a protease inhibitor cocktail. Aliquots containing an equivalent total protein content, as determined by the Bradford's procedure with bovine serum albumin as the standard, were subjected to sodium dodecyl sulfate/4-12 \% polyacrylamide gel electrophoresis, electrotransferred to immobilon-P membranes, and probed overnight with p-eIF2 $\alpha$, elF2 $\alpha$ or GST antibodies. After incubation with a rabbit secondary antibody, a chemiluminescence reagent, and Hyperfilm ECL, bands were quantified by densitometry with Fusion-Capt software (Marne-La vallée, France).

\subsection{Measurement of CYP3A4 activity}

After treatment with DCF \pm TNF- $\alpha$ cells were washed with PBS and incubated at $37^{\circ} \mathrm{C}$ with testosterone dissolved in Williams'E medium without phenol red. After $2 \mathrm{~h}$, medium was collected and CYP3A4 activity was measured using a high performance liquid chromatography equipment (Agilent 1100 series high performance liquid chromatograph equipped with an autosampler and Agilent 1100 series fluorescence and UV detectors) with two solvents, acetic acid ( $0.1 \%)$ and acetonitrile, as previously (Aninat et al., 2006). 


\subsection{Diclofenac biokinetics}

Cultures were incubated with $200 \mu \mathrm{M}$ DCF \pm TNF- $\alpha$ for 2,4 and $24 \mathrm{~h}$; then cell supernatants and lysates were diluted 100 times in the mobile phase and analyzed by Liquid Chromatography - High Resolution - Mass Spectrometer (LC-HR-MS) Q ExactiveTM (Thermo Scientific). An HESI-II ion source was used for the electrospray ionization of target compounds. The chromatographic separation of the analytes was performed with an Accela pump (Thermo Scientific) equipped with a Thermo Fisher C18 Accucore column $(100 \times 2.1 \mathrm{~mm}, 2.6 \mu \mathrm{M})$ using a gradient of $10 \mathrm{mM}$ ammonium acetate buffer containing $0.1 \%(\mathrm{v} / \mathrm{v})$ formic acid and of acetonitrile with $0.1 \%(\mathrm{v} / \mathrm{v})$ formic acid. Retention times were respectively $1.6 \mathrm{~min}$ and $1.3 \mathrm{~min}$ for $\mathrm{DCF}$ and $\mathrm{OH}-$ DCF. Calibration curves were obtained by spiking mobile phase with standards at 0.01 to $10 \mu \mathrm{M}$. Data were acquired in negative Full Scan mode and quantification was performed by extracting the exact mass value of deprotonated DCF $(294.0095 \mathrm{~m} / \mathrm{z})$ and $\mathrm{OH}-\mathrm{DCF}(310.0042 \mathrm{~m} / \mathrm{z})$ using a $5 \mathrm{ppm}$ mass window. 4-OH DCF and 5-OH DCF were not separated chromatographically; consequently $\mathrm{OH}$-metabolites represented the sum of both.

\subsection{Real-Time Quantitative Polymerase Chain Reaction (RT-qPCR) analysis}

Total RNA was extracted from $10^{6}$ HepaRG or HepG2 cells with the SV total RNA isolation system (Promega, Charbonnieres-les-Bains, France). RNAs were reversetranscribed into cDNA and RT-qPCR was performed using a SYBR Green mix. Primer sequences are listed in Supplementary Table 1.

\subsection{Taurocholic acid efflux}

To estimate bile salt export pump (BSEP) activity cells were first exposed to $43.3 \mathrm{nM}$ $\left[{ }^{3} \mathrm{H}\right]$ - taurocholic acid $\left(\left[{ }^{3} \mathrm{H}\right]-T A\right)$ for $30 \mathrm{~min}$, after washing cells were incubated with DCF 
$\pm \mathrm{TNF} \alpha$ in a standard buffer containing $\mathrm{Ca}^{2+}$ and $\mathrm{Mg}^{2+}$. After $2 \mathrm{~h}$ incubation cells were washed and then scraped in $0.1 \mathrm{~N} \mathrm{NaOH}$. The remaining radiolabeled substrate was measured through scintillation counting to determine TA efflux (Antherieu et al., 2013).

\subsection{3. $\mathrm{Na}^{+}$-dependent taurocholate co-transporting polypeptide activity (NTCP)}

NTCP activity was estimated by determination of sodium-dependent intracellular accumulation of $\left[{ }^{3} \mathrm{H}\right]-\mathrm{TA}$ substrate. Cells were treated with DCF \pm TNF- $\alpha$ followed by incubation with $43.3 \mathrm{nM}$ radiolabeled TA for $30 \mathrm{~min}$. Then, they were washed with standard buffer and lysed with $0.1 \mathrm{~N} \mathrm{NaOH}$. Accumulation of radiolabeled substrate was determined through scintillation counting (Sharanek et al., 2015).

\subsection{CDF efflux determination}

After treatment with DCF \pm TNF- $\alpha$ for 4 h cells were incubated with $3 \mu \mathrm{M}$ of 5 (and 6)carboxy-2,7-dichlorofluorescein diacetate (CDFDA) for $30 \mathrm{~min}$ at $37{ }^{\circ} \mathrm{C}$. Upon hydrolysis by intracellular esterases, CDFDA was converted to fluorescent CDF (excitation/emission: 488/509 $\mathrm{nm}$ ) and directed towards the biliary pole by membrane transporters, particularly by the multidrug resistance-associated protein 2 (MRP2). After washing with phenol red-free Williams' E medium. Imaging was performed using a Cellomics ArrayScan VTI HCS Reader (Thermo Scientific) (Bachour-El Azzi et al., 2015).

\subsection{Statistical analysis}

One-way ANOVA with Bonferroni's multiple comparison test (GraphPad Prism 5.00) was performed to compare data between DCF-, TNF- $\alpha-$, DCF + TNF- $\alpha$-treated cells and control cultures. Each value corresponded to the mean \pm standard error of the mean (SEM) of three independent experiments. Data were considered significantly different when $p<0.05$. 


\section{Results}

\subsection{Differential sensitivity of metabolically and non metabolically competent HepaRG cells to DCF}

DCF cytotoxicity was first estimated using the MTT assay after a $24 \mathrm{~h}$ treatment. A decrease in cell viability was observed in a dose-dependent manner with drug concentrations starting at $350 \mu \mathrm{M}(\mathrm{IC} 50 \approx 780 \mu \mathrm{M})$ in differentiated HepaRG cells. Human hepatocytes obtained from three donors showed similar sensitivity to DCF toxicity $(\mathrm{IC} 50 \approx 800 \mu \mathrm{M})$ as differentiated HepaRG cells. Undifferentiated HepaRG (8 days after seeding) and subconfluent HepG2 cells were more sensitive (IC50s $=468$ and $688 \mu \mathrm{M}$ respectively) (Figure 1A-D).

Apoptotic effects of DCF were also estimated by determination of caspase 3 activity. A 1.8-fold augmentation was observed in differentiated HepaRG cells treated with

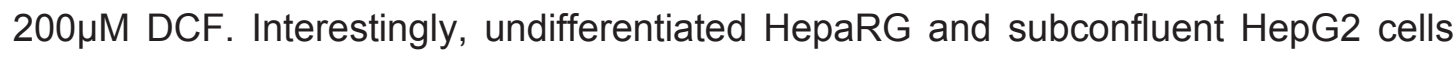
were respectively 3- and 2-fold more sensitive to DCF than differentiated HepaRG cells exposed to $200 \mu \mathrm{M}$ DCF (Fig. 1E and F).

Accordingly, cell examination under phase-contrast microscopy after a $24 \mathrm{~h}$ treatment evidenced some cell detachment in undifferentiated HepaRG and HepG2 cell cultures exposed to $200 \mu \mathrm{M}$ DCF (Fig. 2).

To confirm the lower sensitivity of HepaRG hepatocytes compared to primitive biliary cells, cultures containing $80 \%$ HepaRG hepatocytes (instead of $50 \%$ ) were prepared by cell seeding at high density (Pernelle et al., 2011). In such cultures sensitivity to DCF was further reduced, not exceeding 2.9-fold (versus 5.8-fold) with $350 \mu \mathrm{M}$ (data not shown). Based on all these results, DCF was usually used at $200 \mu \mathrm{M}$ for further investigations. 


\subsection{Diclofenac metabolizing capacity of HepaRG and HepG2 cells}

Drug metabolism capacity of differentiated cells was first evaluated by determination of CYP3A4 activity and transcript levels. CYP3A4 is the main expressed CYP gene in mature hepatocytes and is involved in DCF metabolism (Shen et al., 1999; Tang et al., 1999). As expected, high levels of transcripts and activity were measured in differentiated HepaRG cells; they were not significantly modulated by $200 \mu \mathrm{M}$ DCF (Fig. $3 A$ and $B)$.

Then, in order to determine whether DCF was metabolized by differentiated HepaRG cells, undifferentiated HepaRG cells and HepG2 cells, its biokinetics was estimated over a $24 \mathrm{~h}$ period. DCF and $\mathrm{OH}$-metabolites were measured in both media and cell lysates after 2, 4 and 24h. In differentiated HepaRG cells, the percentage of unchanged DCF recovered in medium and cell layers decreased with time and represented only $14 \%$ of the initial $200 \mu \mathrm{M}$ DCF concentration after $24 \mathrm{~h}$. In parallel, increasing production of $\mathrm{OH}$-metabolites was evidenced (Fig. 3C-F). DCF and/or OH-metabolites did not accumulate intracellularly. Formation of $\mathrm{OH}$-metabolites was completely prevented by co-addition of $300 \mu \mathrm{M}$ 1-aminobenzotriazole (ABT), a non selective inhibitor for human P450s. By contrast, no obvious loss of DCF was evidenced in undifferentiated HepaRG cells (data not shown) and in HepG2 cells after 24h-exposure (Supplementary Fig. 1). All these data supported the conclusion that undifferentiated HepaRG and HepG2 cells had low DCF metabolism capacity if any.

\subsection{Only differentiated HepaRG and HepG2 cells are responsive to TNF-a}

First, differentiated HepaRG cells were exposed to $10 \mathrm{ng} / \mathrm{ml}$ TNF- $\alpha$ and their responsiveness was estimated by determination of CRP and IL-8 transcripts levels and protein secretion rate. CRP and IL-8 secretion levels were measured in the medium of 
untreated and DCF-treated cells in the absence or presence of TNF- $\alpha$ for $24 \mathrm{~h}$ using ELISA assays. Untreated cells secreted $26 \pm 4 \mathrm{pg} / \mathrm{ml} \mathrm{CRP} \mathrm{and} 21 \pm 5 \mathrm{pg} / \mathrm{ml} \mathrm{IL}-8$, and a 37 and $31 \%$ decrease in the release of CRP and IL-8 respectively was evidenced after treatment with $200 \mu \mathrm{M}$ DCF alone, compared to untreated cells. TNF- $\alpha$ strongly increased secretion levels of these two inflammatory markers (12.6- and 41.7-fold for CRP and IL-8 respectively) while a co-treatment with DCF resulted in lower increases (6.1- and 23.3-fold for CRP and IL-8 respectively compared to untreated cells) (Supplementary Fig. 2A and B). All these results were confirmed at mRNA levels by PCR analysis. Co-treatments with $200 \mu \mathrm{M}$ DCF also resulted in lower increase of both protein and transcripts levels (Supplementary Fig. 2C and D).

Then, the influence of TNF- $\alpha$ on DCF cytotoxicity was evaluated using the MTT and caspase 3 activity assays. When differentiated HepaRG cells were exposed to TNF- $\alpha$ for $24 \mathrm{~h}$ before co-exposure to the drug for further $24 \mathrm{~h}$, cytotoxicity was not aggravated in differentiated HepaRG cells using the MTT assay (Fig. 1A) and human hepatocytes (Fig. 1D). However, a significant increase in caspase 3 activity was observed with $200 \mu M$ DCF in combination with TNF- $\alpha$ (5.24-fold vs TNF- $\alpha$ alone) in differentiated cells after pre-treatment with the cytokine (Fig. 1E) while no change and only a slight increase were observed in undifferentiated HepaRG cells and HepG2 cells respectively (Fig. 1E and F). However, treatment with $250 \mu \mathrm{M}$ DCF + TNF- $\alpha$ hugely activated caspase 3 (around 15-fold) in these latter (Fig. 1F).

Since pro-inflammatory cytokines are known to inhibit the major CYPs involved in drug metabolism (Abdel-Razzak et al., 1993), we then investigated whether a pre-treatment with TNF- $\alpha$ could modulate activity and expression of CYP3A4 in differentiated HepaRG cells treated with $200 \mu \mathrm{M}$. Whereas CYP3A4 activity was not significantly modulated by DCF alone, it decreased to $44 \%$ with TNF- $\alpha$ and $34 \%$ with TNF- $\alpha+$ DCF 
(Fig. 3A). CYP3A4 transcript levels dropped by $54 \%$ and $85 \%$ of the control values with TNF- $\alpha$ alone and TNF- $\alpha+$ DCF, respectively (Fig. 3B). Of note, transcripts of CYP2C9, the other CYP involved in DCF metabolism (Shen et al., 1999), were similarly reduced by DCF, TNF- $\alpha$ and co-treatments (Data not shown).

DCF biokinetics and $\mathrm{OH}$-metabolites formation were also measured in cultures of differentiated HepaRG cells co-treated with $200 \mu \mathrm{M}$ DCF and TNF- $\alpha$ over a $24 \mathrm{~h}$ period. A limited decrease in DCF disappearance was observed with TNF- $\alpha+$ DCF $(27 \%)$ compared to DCF alone (14\%). Accordingly, a slight decrease in the formation of $\mathrm{OH}-$ metabolites was observed with TNF- $\alpha+$ DCF $(22 \%)$ compared to DCF alone (28\%). Noteworthy, ABT decreased DCF disappearance to $57 \%$ and completely inhibited $\mathrm{OH}$ metabolites formation (Fig. 3C-G). As found with DCF alone no obvious loss of DCF and formation of $\mathrm{OH}$-metabolites were evidenced in undifferentiated HepaRG (data not shown) and HepG2 cells after treatment with the combination DCF + TNF- $\alpha$ (Supplementary Fig. 1).

\subsection{DCF-induced generation of oxidative stress}

Treatment of differentiated HepaRG cells with DCF alone did not induce generation of detectable oxidative stress at concentrations up to $200 \mu \mathrm{M}$, even after $24 \mathrm{~h}$ as shown by measurement of reactive oxidative species (ROS) using the DCFDA assay. However, a first treatment with TNF- $\alpha$ followed by co-treatment with $200 \mu \mathrm{M}$ DCF caused a slight generation of ROS within the first $8 \mathrm{~h}$ which reached 3.5 -fold after $24 \mathrm{~h}$ (Fig. 4A). Transcript levels of the two oxidative stress-related genes HO-1 and MnSOD were also slightly augmented in differentiated HepaRG cells, i.e. 1.4- and 1.5-fold, after treatment with $200 \mu \mathrm{M} \mathrm{DCF}$ and 1.6- and 2-fold after co-treatment with DCF + TNF- $\alpha$ respectively after $24 \mathrm{~h}$ (Fig. $4 \mathrm{~B}$ and C). 
A slight production of ROS was detected in undifferentiated HepaRG cells during the the first $8 \mathrm{~h}$ after treatment with $200 \mu \mathrm{M} \mathrm{DCF}$ (1.4-fold); this production reached 2.8 -fold after 24h (Fig. 4D). Noticeably, HO-1 and MnSOD gene expression was also augmented in undifferentiated HepaRG cells exposed to DCF alone (3.6- and 3.1-fold respectively) and slightly more after co-treatment with DCF + TNF- $\alpha$, reaching 3.9- and 3.3-fold for HO-1 and MnSOD respectively (Fig. 4E and F).

In addition, ROS generation was measured in the presence of NAC, z-LEHD-fmk and etanercept. A high inhibition of ROS generation was observed in the presence of NAC in undifferentiated HepaRG cells treated with DCF alone, and in differentiated HepaRG cells treated with DCF + TNF- $\alpha$, and in the presence of etanercept in co-treated differentiated HepaRG cells. Z-LEHD-fmk exerted only a slight inhibition of ROS production (Supplementary Fig. 3A and B).

\subsection{Enhancement of DCF-induced ER stress by TNF- $\alpha$ in differentiated cells}

A specific activation of the ER stress route through the ATF4 transcriptional activity has also been reported in DCF-treated liver cells (Fredriksson et al., 2014). Our results showed that transcripts levels of ATF4, ATF6, CHOP and GRP78 were all overexpressed in differentiated HepaRG cells exposed to $200 \mu \mathrm{M}$ DCF for $24 \mathrm{~h}$. The increases were significant with $200 \mu \mathrm{M}$ for the 4 genes and co-treatment with TNF- $\alpha$ led to a further significant increase. CHOP was more up-regulated than ATF4 and ATF6 (Fig. 5A-D).

These 4 genes were more responsive to DCF in undifferentiated HepaRG cells; they were already overexpressed with $50 \mu \mathrm{M}$ and their increase reached values between

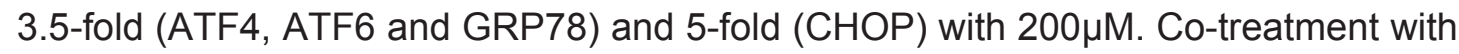
TNF- $\alpha$ did not further enhance expression of these 4 genes (Fig. 5E-H). 
Phosphorylation of elF2 $\alpha$, the upstream regulator of CHOP and ATF4 (Oslowski and Urano, 2011), was also analyzed by western blotting after $2 \mathrm{~h}$ of treatment. While it had no obvious effect in differentiated HepaRG cells, the combination TNF- $\alpha+$ DCF increased p-elF2 in undifferentiated HepaRG cells compared to DCF-treated cells (Fig. $6 \mathrm{~A}$ and $\mathrm{B})$.

\subsection{Modulation of caspases 8, 9 and 3 activities by DCF and TNF- $\alpha$}

We further analyzed whether DCF \pm TNF- $\alpha$ altered activity of the two initiator caspases 8 and 9. DCF alone increased nearly 2 -fold more caspase 9 than caspase 8 (3.1versus 1.7-fold) in differentiated cells and more strongly both caspases in undifferentiated cells (5.4- and 2.4-fold caspases 9 and 8 respectively). As expected, compared to DCF alone co-treatment with TNF- $\alpha$ strongly enhanced caspase 8 in differentiated cells and only slightly in their undifferentiated counterparts. Caspase 9 was slightly enhanced if any in both differentiated and undifferentiated cells by cotreatment (Fig. 7A-D).

To confirm the involvement of caspase 3,8 and 9 in DCF +/- TNF- $\alpha$ toxicity, cells were co-treated with different inhibitors, i.e. NAC, z-LEHD-fmk and etanercept. In DCFtreated differentiated HepaRG cells the slight increase of caspase 8 was nearly completely abolished by NAC and z-LEHD-fmk, and caspase 9 activation was also strongly reduced by these two inhibitors (i.e. 66.7 and $94.8 \%$ respectively) (Fig. 7C). Additional caspase 8 activation by DCF + TNF- $\alpha$ co-treatment was mostly abolished $(85 \%)$ in the presence of etanercept. NAC and z-LEHD-fmk also strongly inhibited caspases 8 and 9 in DCF-treated undifferentiated HepaRG cells reaching 86 and $87.9 \%$ for the former and 65.3 and $95.9 \%$ for the latter respectively. As expected, addition of etanercept was without any effect (Fig. 7B and C). The effects of the 
different inhibitors in HepG2 cells treated with DCF or DCF + TNF- $\alpha$ were comparable to those observed in differentiated HepaRG cells treated in similar conditions (Supplementary Fig. 5). Activation of caspase 3 by DCF and DCF + TNF- $\alpha$ reflected changes in caspases 9 and/or 8 in the three cell models (Supplementary Fig. 4).

\subsection{Sensitivity to DCF is inversely correlated to GST content}

Several studies have demonstrated that GSTs play a key role in detoxifying processes (Board and Menon, 2013). We have analyzed GST A1/2 and M1/2 content in both differentiated and undifferentiated HepaRG cells, and in HepG2 cells. As shown in Fig. 8 both GSTs were less abundant in undifferentiated HepaRG cells (72.6 and $59.8 \%$ less for $A 1 / 2$ and $M 1 / 2$ respectively) and in HepG2 cells (35.6 and $17.51 \%$ less for A1/2 and M1/2 respectively) than in differentiated HepaRG cells (Fig. 8A-D).

Similarly, co-treatment of differentiated HepaRG cells with DCF + TNF- $\alpha$ caused a decrease in transcript levels of the two GST isoforms (35.5, and $37.2 \%$ for GST A $1 / 2$ and GST M1/2 respectively), compared to treatment with DCF alone (Fig. 8E and F). Moreover, to confirm the protective role of GSTs against DCF cytotoxicity differentiated HepaRG cells were co-exposed to $10 \mu \mathrm{M}$ ethacrynic acid, a GST inhibitor (Awasthi et al., 1993), for $24 \mathrm{~h}$ before determination of caspase 3 activity. As expected, DCF cytotoxicity was significantly enhanced (Fig. 9).

\subsection{DCF-induced cholestatic features are not influenced by co-treatment with TNF-a}

To determine whether DCF induced cholestatic effects in the presence or absence of TNF-a, differentiated HepaRG cells were regularly examined under phase-contrast microscopy following DCF \pm TNF- $\alpha$ addition. Dilatation of many bile canaliculi was 
observed after $6 \mathrm{~h}$ with $50 \mu \mathrm{M}$ DCF (data not shown). Dilatations appeared as early as 1h treatment with 100 and $200 \mu M$ DCF (Fig. 10A). TNF- $\alpha$ alone had no effect and did not potentiate bile canaliculi deformations caused by DCF (Fig. 10A).

To look for whether DCF-induced bile canaliculi deformations were associated with alterations of bile acids transport, activities of NTCP and BSEP were measured using $\left[{ }^{3} \mathrm{H}\right]$-taurocholic acid as substrate. NTCP activity was slightly reduced after $24 \mathrm{~h}$ treatment with $200 \mu \mathrm{M}$ DCF whereas it was strongly inhibited by TNF- $\alpha$ alone (Fig. 10B). By contrast, a dose-dependent augmentation of BSEP activity was evidenced with DCF alone without any further significant change by co-treatment with TNF- $\alpha$ after 2h (Supplementary Fig. 6). Both NTCP and BSEP transcripts were decreased by DCF and more extensively by co-treatment with TNF- $\alpha$ after $24 \mathrm{~h}$. Noticeably, CDF accumulated in dilatated bile canaliculi of DCF-treated cells (Fig. 10A).

\section{Discussion}

Formation of reactive CYP-mediated $4^{\prime} \mathrm{OH}-$ and $5^{\prime} \mathrm{OH}$-metabolites and/or acyl glucuronides from DCF has been associated with induction of intrinsic apoptosis resulting from ROS generation and alteration of the mitochondrial function both in rat and human hepatocytes (Gomez-Lechon et al., 2003a; Masubuchi et al., 2002) and in HepG2 cells (Fredriksson et al., 2014). In the current study, we demonstrated that DCF caused cytotoxicity in the absence of any biotransformation by comparing metabolically and non-metabolically competent HepaRG cells. Indeed, undifferentiated HepaRG cells as well as HepG2 cells which exhibited low CYP activity if any, and did not form DCF-OH metabolites were more sensitive to the drug than HepaRG hepatocytes. The capacity of differentiated HepaRG cells to actively metabolize DCF 
was verified by biokinetics analysis showing that drug disappearance was associated with formation of $\mathrm{OH}$-metabolites.

Accordingly, primitive biliary cells were also found to be more sensitive than HepaRG hepatocytes to DCF in differentiated HepaRG cell cultures, further supporting that DCF could induce cytotoxicity in the absence of any metabolism. Moreover, sensitivity to DCF was found to be further reduced in differentiated HepaRG cell cultures when the percentage of HepaRG hepatocytes increased from 50 to $80 \%$. The higher sensitivity of non-metabolically competent liver cells could be related to the capability of DCF to induce toxicity in several organs and non-hepatic cells. Indeed, DCF is also a powerful nephrotoxicant. DCF treatments have been associated with a number of cases of acute renal failure in humans (Rubio Garcia and Tellez Molina, 1992); they have also been shown to cause marked nephrotoxic effects in mouse in absence of evidence of any liver damage determined by serum alanine transaminase measurements, indicating that contribution of DCF metabolism and its consequences in the liver were not confounding factors towards culminating nephrotoxicity (Hickey et al., 2001). In agreement, the $250 \mu \mathrm{M}$ EC50 value reported with DCF-treated kidney LLC-PK1 pig cells (Ng et al., 2008) was lower than the value obtained with differentiated HepaRG cells $(780 \mu \mathrm{M}$, this study). Similarly, DCF-induced intestinal toxicity was recently found to be unrelated to its metabolism using precision-cut human intestinal slices (Niu et al., 2015). Noteworthy, while $70 \%$ of the patients receiving DCF therapy developed intestinal adverse effects (Zhu and Zhang, 2012) the risk of liver injury reached only 6 per 100000 users with chronic DCF administration (de Abajo et al., 2004).

DCF induced an apoptotic response in both differentiated and undifferentiated HepaRG cell models at lower concentrations than necrosis, as shown by using caspase 3 activation and MTT assays, in agreement with previous studies using other 
liver cell models (Fredriksson et al., 2011; Gomez-Lechon et al., 2003b). The higher apoptotic response of non-metabolically competent liver cells to DCF was associated with generation of more reactive oxygen species, higher expression of the two oxidative stress-related genes $\mathrm{HO} 1$ and MnSOD and ER-stress-related genes, and higher activation of caspases 8,9 and 3. Apoptosis can occur via two pathways: the intrinsic resulting from mitochondrial dysfunction and the extrinsic resulting from activation of external death receptors. It has been proposed that DCF-induced apoptosis is mainly mediated by the mitochondrial pathway, which involved generation of ROS and ER stresses, induction of the mitochondrial pore transition and activation of JNK (Fredriksson et al., 2014; Gomez-Lechon et al., 2003a; Masubuchi et al., 2002). In support, it has been shown that DCF could act as an uncoupler of oxidative phosphorylation in mitochondria (LoGuidice et al., 2012; Somasundaram, 2001). Our results agree with these conclusions. Indeed, co-treatments of DCF with the antioxidant NAC or the caspase 9 inhibitor z-LEHD-fmk largely prevented caspases 9 and 3 activation, suggesting that oxidative and ER stresses mediating mitochondrial pore transition were crucial events in DCF-induced apoptosis in differentiated and undifferentiated HepaRG cells. Similarly, DCF activation of these different caspases in HepG2 cells was also strongly reduced with NAC and z-LEHD-fmk, further supporting the prominent involvement of the intrinsic pathway as previously reported (Masubuchi et al., 2002).

Pro-inflammatory cytokines are known to severely enhance liver injury induced by various xenobiotics including DCF (Ramm and Mally, 2013). We showed here that TNF- $\alpha$ potentiated DCF toxicity in differentiated HepaRG cells, mainly through activation of caspases 8 and 3 . Similar results, although to a lower extent, were obtained with HepG2 cells while undifferentiated HepaRG cells were nearly 
unresponsive. The higher apoptotic response previously reported in HepG2 cells cotreated with DCF+TNF- $\alpha$ could likely be explained by the use of higher DCF

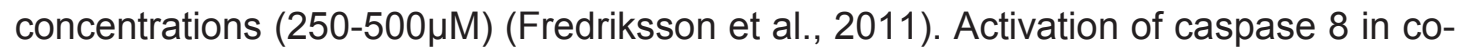
treated differentiated HepaRG cells and HepG2 cells was mostly inhibited by etanercept, supporting the involvement of the extrinsic apoptotic pathway in potentiation of DCF cytotoxicity by TNF- $\alpha$. Of note, the two TNF- $\alpha$ receptors (R1 and R2) were well expressed in these cells while they were barely detectable in undifferentiated HepaRG cells, thus explaining the unresponsiveness of these latter to TNF- $\alpha$ when combined with DCF (Supplementary Table 2).

Differentiated HepaRG cells contain large amounts of detoxifying enzymes (Aninat et al., 2006; Gerets et al., 2012; Rogue et al., 2012), that could contribute to inactivation of DCF reactive metabolites and protection against apoptotic effects of the drug. DCF quinone imine metabolites have been shown to be reduced by $N A D(P) H: q u i n o n e$ oxido-reductase1 and conjugated to GSH by GSTs (Dragovic et al., 2013; Vredenburg et al., 2014). Our data confirming that differentiated HepaRG cells contained higher levels of GST A1/2 and M1/2 than their undifferentiated counterparts and HepG2 cells and showing their higher sensitivity to DCF following GST inhibition by ethacrynic acid, brought further support to their lower sensitivity to apoptotic effects of DCF. Moreover, the higher sensitivity of differentiated HepaRG cells to apoptotic effects of DCF following pre-exposure to TNF- $\alpha$, which is associated with inhibition of CYPs and GSTs, as well as the comparable sensitivity of primary human hepatocytes and differentiated HepaRG cells to DCF supported our conclusions. Noticeably, a lower sensitivity of differentiated HepaRG cells compared to HepG2 cells has previously been reported for several known hepatotoxic chemicals (Gerets et al., 2012). Accordingly, the differential sensitivity of differentiated HepaRG cells and HepG2 cells 
to DCF could be related to differences in both oxidative metabolism and detoxifying and antioxidant capacities. However, it cannot be excluded that GSTs were partly acting via their anti-apoptotic properties (Board and Menon, 2013; Gilot et al., 2002). Likelihood, its high content in GSTs and other detoxifying enzymes could also at least partly explain the lower sensitivity to DCF of the liver compared to other tissues.

Besides its capacity to induce hepatocellular injury DCF can also cause cholestasis in humans. As observed with several other cholestatic drugs (Sharanek et al., 2016), we found that DCF provoked early dilatation of bile canaliculi at lower concentrations than those causing cytotoxicity and these bile canaliculi deformations were associated with alterations of taurocholic acid clearance as well as of expression of influx and efflux bile acid transporters. Although TNF- $\alpha$ did not obviously alter these major DCF cholestatic effects when added prior to and/or simultaneously with the drug this did not exclude that this cytokine could modulate bile acids synthesis and/or secretion.

Altogether our results bring new insights in DCF-induced cytotoxicity and its potentiation by TNF- $\alpha$. They demonstrate that DCF toxicity to human liver cells can occur in absence of biotransformation and through the intrinsic apoptotic pathway, and be related to the phenotype while its potentiation by TNF- $\alpha$ can be observed only in cells expressing death receptors and involves the extrinsic pathway. The lower sensitivity of human HepaRG hepatocytes to DCF-induced apoptosis can be explained by their high content in glutathione transferases and consequently by their ability to inactivate DCF reactive metabolites.

\section{Financial support}

This work was supported by the European Community [Contract MIP-DILI-115336]. The MIP-DILI project has received support from the Innovative Medicines Initiative 
Joint Undertaking, resources of which are composed of financial contribution from the European Union's Seventh Framework Programme [FP7/20072013] and EFPIA companies' in kind contribution. http://www.imi.europa.eu/.

Houssein Al-Attrache was financially supported by the Association AZM-Lebanese University and the MIP-DILI project; Ahmad Sharanek by the Lebanese Association for Scientific Research (LASeR) and the MIP-DILI project, Audrey Burban by the MIP-DILI project and Matthew Burbank by a CIFRE contract with Servier.

Disclosures: The authors declare that there are no conflicts of interest. 


\section{References}

Abdel-Razzak, Z., Loyer, P., Fautrel, A., Gautier, J.C., Corcos, L., Turlin, B., Beaune, P., Guillouzo, A., 1993. Cytokines down-regulate expression of major cytochrome P450 enzymes in adult human hepatocytes in primary culture. Mol Pharmacol 44, 707715.

Aithal, G.P., Day, C.P., 2007. Nonsteroidal anti-inflammatory drug-induced hepatotoxicity. Clin Liver Dis 11, 563-575, vi-vii.

Aninat, C., Piton, A., Glaise, D., Le Charpentier, T., Langouet, S., Morel, F., GuguenGuillouzo, C., Guillouzo, A., 2006. Expression of cytochromes P450, conjugating enzymes and nuclear receptors in human hepatoma HepaRG cells. Drug Metab Dispos 34, 75-83.

Antherieu, S., Bachour-El Azzi, P., Dumont, J., Abdel-Razzak, Z., Guguen-Guillouzo, C., Fromenty, B., Robin, M.A., Guillouzo, A., 2013. Oxidative stress plays a major role in chlorpromazine-induced cholestasis in human HepaRG cells. Hepatology 57, 15181529.

Awasthi, S., Srivastava, S.K., Ahmad, F., Ahmad, H., Ansari, G.A., 1993. Interactions of glutathione S-transferase-pi with ethacrynic acid and its glutathione conjugate. Biochim Biophys Acta 1164, 173-178.

Bachour-El Azzi, P., Sharanek, A., Abdel-Razzak, Z., Antherieu, S., Al-Attrache, H., Savary, C.C., Lepage, S., Morel, I., Labbe, G., Guguen-Guillouzo, C., Guillouzo, A., 2014. Impact of inflammation on chlorpromazine-induced cytotoxicity and cholestatic features in HepaRG cells. Drug Metab Dispos 42, 1556-1566.

Bachour-El Azzi, P., Sharanek, A., Burban, A., Li, R., Guevel, R.L., Abdel-Razzak, Z., Stieger, B., Guguen-Guillouzo, C., Guillouzo, A., 2015. Comparative Localization and 
Functional Activity of the Main Hepatobiliary Transporters in HepaRG Cells and Primary Human Hepatocytes. Toxicological sciences : an official journal of the Society of Toxicology 145, 157-168.

Banks, A.T., Zimmerman, H.J., Ishak, K.G., Harter, J.G., 1995. Diclofenac-associated hepatotoxicity: analysis of 180 cases reported to the Food and Drug Administration as adverse reactions. Hepatology 22, 820-827.

Bjornsson, E., Olsson, R., 2006. Suspected drug-induced liver fatalities reported to the WHO database. Dig Liver Dis 38, 33-38.

Board, P.G., Menon, D., 2013. Glutathione transferases, regulators of cellular metabolism and physiology. Biochim Biophys Acta 1830, 3267-3288.

Bort, R., Ponsoda, X., Jover, R., Gomez-Lechon, M.J., Castell, J.V., 1999. Diclofenac toxicity to hepatocytes: a role for drug metabolism in cell toxicity. J Pharmacol Exp Ther 288, 65-72.

Breen, E.G., McNicholl, J., Cosgrove, E., McCabe, J., Stevens, F.M., 1986. Fatal hepatitis associated with diclofenac. Gut 27, 1390-1393.

Cerec, V., Glaise, D., Garnier, D., Morosan, S., Turlin, B., Drenou, B., Gripon, P., Kremsdorf, D., Guguen-Guillouzo, C., Corlu, A., 2007. Transdifferentiation of hepatocyte-like cells from the human hepatoma HepaRG cell line through bipotent progenitor. Hepatology 45, 957-967.

de Abajo, F.J., Montero, D., Madurga, M., Garcia Rodriguez, L.A., 2004. Acute and clinically relevant drug-induced liver injury: a population based case-control study. $\mathrm{Br}$ J Clin Pharmacol 58, 71-80.

Deng, X., Stachlewitz, R.F., Liguori, M.J., Blomme, E.A., Waring, J.F., Luyendyk, J.P., Maddox, J.F., Ganey, P.E., Roth, R.A., 2006. Modest inflammation enhances 
diclofenac hepatotoxicity in rats: role of neutrophils and bacterial translocation. $\mathrm{J}$ Pharmacol Exp Ther 319, 1191-1199.

Dragovic, S., Boerma, J.S., Vermeulen, N.P., Commandeur, J.N., 2013. Effect of human glutathione S-transferases on glutathione-dependent inactivation of cytochrome P450-dependent reactive intermediates of diclofenac. Chem Res Toxicol $26,1632-1641$.

Dumont, J., Josse, R., Lambert, C., Antherieu, S., Le Hegarat, L., Aninat, C., Robin, M.A., Guguen-Guillouzo, C., Guillouzo, A., 2010. Differential toxicity of heterocyclic aromatic amines and their mixture in metabolically competent HepaRG cells. Toxicol Appl Pharmacol 245, 256-263.

Fredriksson, L., Herpers, B., Benedetti, G., Matadin, Q., Puigvert, J.C., de Bont, H., Dragovic, S., Vermeulen, N.P., Commandeur, J.N., Danen, E., de Graauw, M., van de Water, B., 2011. Diclofenac inhibits tumor necrosis factor-alpha-induced nuclear factor-kappaB activation causing synergistic hepatocyte apoptosis. Hepatology 53, 2027-2041.

Fredriksson, L., Wink, S., Herpers, B., Benedetti, G., Hadi, M., de Bont, H., Groothuis, G., Luijten, M., Danen, E., de Graauw, M., Meerman, J., van de Water, B., 2014. Druginduced endoplasmic reticulum and oxidative stress responses independently sensitize toward TNFalpha-mediated hepatotoxicity. Toxicol Sci 140, 144-159.

Gerets, H.H., Tilmant, K., Gerin, B., Chanteux, H., Depelchin, B.O., Dhalluin, S., Atienzar, F.A., 2012. Characterization of primary human hepatocytes, HepG2 cells, and HepaRG cells at the mRNA level and CYP activity in response to inducers and their predictivity for the detection of human hepatotoxins. Cell Biol Toxicol 28, 69-87. 
Gilot, D., Loyer, P., Corlu, A., Glaise, D., Lagadic-Gossmann, D., Atfi, A., Morel, F., Ichijo, H., Guguen-Guillouzo, C., 2002. Liver protection from apoptosis requires both blockage of initiator caspase activities and inhibition of ASK1/JNK pathway via glutathione S-transferase regulation. J Biol Chem 277, 49220-49229.

Gomez-Lechon, M.J., Ponsoda, X., O'Connor, E., Donato, T., Castell, J.V., Jover, R., 2003a. Diclofenac induces apoptosis in hepatocytes by alteration of mitochondrial function and generation of ROS. Biochem Pharmacol 66, 2155-2167.

Gomez-Lechon, M.J., Ponsoda, X., O'Connor, E., Donato, T., Jover, R., Castell, J.V., 2003b. Diclofenac induces apoptosis in hepatocytes. Toxicol In Vitro 17, 675-680.

Guguen-Guillouzo, C., Campion, J.P., Brissot, P., Glaise, D., Launois, B., Bourel, M., Guillouzo, A., 1982. High yield preparation of isolated human adult hepatocytes by enzymatic perfusion of the liver. Cell Biol Int Rep 6, 625-628.

Guillouzo, A., Guguen-Guillouzo, C., 2008. Evolving concepts in liver tissue modeling and implications for in vitro toxicology. Expert Opin Drug Metab Toxicol 4, 1279-1294. Hickey, E.J., Raje, R.R., Reid, V.E., Gross, S.M., Ray, S.D., 2001. Diclofenac induced in vivo nephrotoxicity may involve oxidative stress-mediated massive genomic DNA fragmentation and apoptotic cell death. Free Radic Biol Med 31, 139-152.

Jouan-Lanhouet, S., Arshad, M.I., Piquet-Pellorce, C., Martin-Chouly, C., Le MoigneMuller, G., Van Herreweghe, F., Takahashi, N., Sergent, O., Lagadic-Gossmann, D., Vandenabeele, P., Samson, M., Dimanche-Boitrel, M.T., 2012. TRAIL induces necroptosis involving RIPK1/RIPK3-dependent PARP-1 activation. Cell Death Differ 19, 2003-2014. 
Kretz-Rommel, A., Boelsterli, U.A., 1993. Diclofenac covalent protein binding is dependent on acyl glucuronide formation and is inversely related to P450-mediated acute cell injury in cultured rat hepatocytes. Toxicol Appl Pharmacol 120, 155-161.

LoGuidice, A., Wallace, B.D., Bendel, L., Redinbo, M.R., Boelsterli, U.A., 2012. Pharmacologic targeting of bacterial beta-glucuronidase alleviates nonsteroidal antiinflammatory drug-induced enteropathy in mice. J Pharmacol Exp Ther 341, 447-454.

Maccarrone, M., Lorenzon, T., Bari, M., Melino, G., Finazzi-Agro, A., 2000. Anandamide induces apoptosis in human cells via vanilloid receptors. Evidence for a protective role of cannabinoid receptors. J Biol Chem 275, 31938-31945.

Maianski, N.A., Roos, D., Kuijpers, T.W., 2004. Bid truncation, bid/bax targeting to the mitochondria, and caspase activation associated with neutrophil apoptosis are inhibited by granulocyte colony-stimulating factor. J Immunol 172, 7024-7030.

Maiuri, A.R., Breier, A.B., Gora, L.F., Parkins, R.V., Ganey, P.E., Roth, R.A., 2015. Cytotoxic Synergy Between Cytokines and NSAIDs Associated With Idiosyncratic Hepatotoxicity Is Driven by Mitogen-Activated Protein Kinases. Toxicol Sci 146, 265280.

Masubuchi, Y., Nakayama, S., Horie, T., 2002. Role of mitochondrial permeability transition in diclofenac-induced hepatocyte injury in rats. Hepatology 35, 544-551.

Ng, L.E., Halliwell, B., Wong, K.P., 2008. Nephrotoxic cell death by diclofenac and meloxicam. Biochem Biophys Res Commun 369, 873-877.

Niu, X., de Graaf, I.A., Langelaar-Makkinje, M., Horvatovich, P., Groothuis, G.M., 2015. Diclofenac toxicity in human intestine ex vivo is not related to the formation of intestinal metabolites. Arch Toxicol 89, 107-119. 
Oslowski, C.M., Urano, F., 2011. Measuring ER stress and the unfolded protein response using mammalian tissue culture system. Methods in enzymology 490, 71-92.

Pernelle, K., Le Guevel, R., Glaise, D., Stasio, C.G., Le Charpentier, T., Bouaita, B., Corlu, A., Guguen-Guillouzo, C., 2011. Automated detection of hepatotoxic compounds in human hepatocytes using HepaRG cells and image-based analysis of mitochondrial dysfunction with JC-1 dye. Toxicol Appl Pharmacol 254, 256-266.

Ramm, S., Mally, A., 2013. Role of drug-independent stress factors in liver injury associated with diclofenac intake. Toxicology 312, 83-96.

Rogue, A., Lambert, C., Spire, C., Claude, N., Guillouzo, A., 2012. Interindividual variability in gene expression profiles in human hepatocytes and comparison with HepaRG cells. Drug Metab Dispos 40, 151-158.

Rubio Garcia, J.A., Tellez Molina, M.J., 1992. [Acute renal failure and nephrotic syndrome associated with treatment with diclofenac]. Rev Clin Esp 191, 289-290.

Seitz, S., Boelsterli, U.A., 1998. Diclofenac acyl glucuronide, a major biliary metabolite, is directly involved in small intestinal injury in rats. Gastroenterology 115, 1476-1482.

Seitz, S., Kretz-Rommel, A., Oude Elferink, R.P., Boelsterli, U.A., 1998. Selective protein adduct formation of diclofenac glucuronide is critically dependent on the rat canalicular conjugate export pump (Mrp2). Chem Res Toxicol 11, 513-519.

Sharanek, A., Azzi, P.B., Al-Attrache, H., Savary, C.C., Humbert, L., Rainteau, D., Guguen-Guillouzo, C., Guillouzo, A., 2014. Different dose-dependent mechanisms are involved in early cyclosporine a-induced cholestatic effects in hepaRG cells. Toxicol Sci 141, 244-253.

Sharanek, A., Burban, A., Burbank, M., Le Guevel, R., Li, R., Guillouzo, A., GuguenGuillouzo, C., 2016. Rho-kinase/myosin light chain kinase pathway plays a key role in 
the impairment of bile canaliculi dynamics induced by cholestatic drugs. Sci Rep 6, 24709.

Sharanek, A., Burban, A., Humbert, L., Bachour-El Azzi, P., Felix-Gomes, N., Rainteau, D., Guillouzo, A., 2015. Cellular Accumulation and Toxic Effects of Bile Acids in Cyclosporine A-Treated HepaRG Hepatocytes. Toxicol Sci 147, 573-587.

Shen, S., Marchick, M.R., Davis, M.R., Doss, G.A., Pohl, L.R., 1999. Metabolic activation of diclofenac by human cytochrome P450 3A4: role of 5-hydroxydiclofenac. Chem Res Toxicol 12, 214-222.

Somasundaram, S., 2001. Pathogenesis of diclofenac enteropathy. Gastroenterology 120, 1885; author reply 1886-1887.

Son, T.W., Yun, S.P., Yong, M.S., Seo, B.N., Ryu, J.M., Youn, H.Y., Oh, Y.M., Han, H.J., 2013. Netrin-1 protects hypoxia-induced mitochondrial apoptosis through HSP27 expression via DCC- and integrin alpha6beta4-dependent Akt, GSK-3beta, and HSF1 in mesenchymal stem cells. Cell Death Dis 4, e563.

Tang, W., Stearns, R.A., Wang, R.W., Chiu, S.H., Baillie, T.A., 1999. Roles of human hepatic cytochrome P450s 2C9 and 3A4 in the metabolic activation of diclofenac. Chem Res Toxicol 12, 192-199.

Uetrecht, J., 2006. Evaluation of which reactive metabolite, if any, is responsible for a specific idiosyncratic reaction. Drug Metab Rev 38, 745-753.

Vredenburg, G., Elias, N.S., Venkataraman, H., Hendriks, D.F., Vermeulen, N.P., Commandeur, J.N., Vos, J.C., 2014. Human NAD(P)H:quinone oxidoreductase 1 (NQO1)-mediated inactivation of reactive quinoneimine metabolites of diclofenac and mefenamic acid. Chem Res Toxicol 27, 576-586. 
Wang, A.G., Xia, T., Yuan, J., Yu, R.A., Yang, K.D., Chen, X.M., Qu, W., Waalkes, M.P., 2004. Effects of phenobarbital on metabolism and toxicity of diclofenac sodium in rat hepatocytes in vitro. Food Chem Toxicol 42, 1647-1653.

Watanabe, N., Takashimizu, S., Kojima, S., Kagawa, T., Nishizaki, Y., Mine, T., Matsuzaki, S., 2007. Clinical and pathological features of a prolonged type of acute intrahepatic cholestasis. Hepatol Res 37, 598-607.

Zeng, T., Zhang, C.L., Song, F.Y., Zhao, X.L., Xie, K.Q., 2014. CMZ reversed chronic ethanol-induced disturbance of PPAR-alpha possibly by suppressing oxidative stress and PGC-1alpha acetylation, and activating the MAPK and GSK3beta pathway. PLoS One 9, e98658.

Zhu, Y., Zhang, Q.Y., 2012. Role of intestinal cytochrome p450 enzymes in diclofenacinduced toxicity in the small intestine. J Pharmacol Exp Ther 343, 362-370. 


\section{Figure legends}

Fig. 1. Influence of TNF- $\alpha$ on DCF-induced toxicity in differentiated and undifferentiated HepaRG cells, HepG2 cells and primary human hepatocytes.

Cells were treated with diclofenac $(\mathrm{DCF}) \pm \mathrm{TNF}$ - $\alpha$ following pre-treatment or not with the cytokine. (A-D) MTT assay in the four cell models and (E) Caspase 3 activity in differentiated and undifferentiated HepaRG cells after treatment with DCF \pm TNF- $\alpha$. (F) Caspase 3 activity in HepG2 cells after the same treatments as in (E). All results are expressed relative to the levels found in corresponding untreated cells, arbitrarily set at a value of 1 or $100 .{ }^{\star} P<0.05,{ }^{*} P<0.01$ and ${ }^{* \star *} P<0.001$ compared with untreated cells, ${ }^{\#} P<0.05$ and ${ }^{\# \#} P<0.001$ compared with cells treated with TNF- $\alpha$ or DCF individually.

Fig. 2. Effects of DCF and TNF-a on morphology of differentiated HepaRG, undifferentiated HepaRG and HepG2 cells

Phase-contrast microscopy examination of differentiated HepaRG, undifferentiated HepaRG and HepG2 cells after treatment with TNF- $\alpha$ for $24 \mathrm{~h}$ followed by $24 \mathrm{~h}$ cotreatment with $200 \mu \mathrm{M}$ DCF \pm TNF- $\alpha$. White arrows demonstrate cell alterations characterized by cell detachment.

Fig. 3. Effects of DCF and TNF- $\alpha$ on CYP3A4 activity and transcript levels and analysis of DCF biokinetics

Differentiated HepaRG cells were exposed to DCF \pm TNF- $\alpha$. (A) CYP3A4 activity determined by HPLC and (B) CYP mRNA levels measured by RT-PCR analysis. Unchanged DCF and OH-metabolites were measured by LC-HR-MS in both 
supernatants $(C$ and $D)$ and cell layers $(E$ and $F)$ after treatment with $D C F$ alone or the combination DCF+TNF- $\alpha$ in differentiated HepaRG cells. Results in (A) and (B) are expressed relative to the levels found in control cells, arbitrarily set at a value of 100 or 1. Results in (C-F) are expressed relative to the levels found in unexposed media containing $200 \mu \mathrm{M}$ DCF, arbitrarily set at a value of $100 .{ }^{*} P<0.05$ and ${ }^{\star \star *} P<0.001$

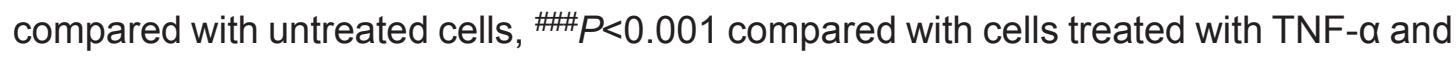
DCF individually.

Fig. 4. Effects of DCF \pm TNF- $\alpha$ on ROS generation and expression of HO-1 and MnSOD genes in differentiated and undifferentiated HepaRG cells

Following exposure of cells to DCF \pm TNF- $\alpha$ ROS generation was measured after 30 min, $2 \mathrm{~h}, 4 \mathrm{~h}, 8 \mathrm{~h}$ and $24 \mathrm{~h}$, using the $\mathrm{H}_{2}$ DCFDA assay and $\mathrm{HO}-1$ and MnSOD transcripts levels were determined by RT-PCR analysis in (A, B and C) differentiated and (D, E and F) undifferentiated HepaRG cells. H2O2 (25 mM) was used as positive control after $2 \mathrm{~h}$ treatment. All results are expressed relative to the levels found in control cells, arbitrarily set at a value of $1 .{ }^{*} P<0.05,{ }^{\star \star} P<0.01$ and ${ }^{\star \star *} P<0.001$ compared

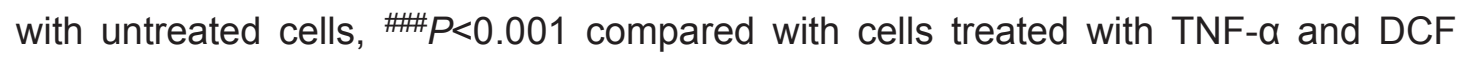
individually.

Fig. 5. Transcript levels of ER stress genes after treatment with DCF \pm TNF- $\alpha$.

ATF4, ATF6, CHOP and GRP78 gene expression was measured in differentiated (A, B, C and D) and undifferentiated HepaRG cells (E, F, G and H). All results are expressed relative to the corresponding levels found in control cells, arbitrarily set at a value of $1 .{ }^{* *} \mathrm{P}<0.01$ and ${ }^{* * *} \mathrm{P}<0.001$ compared with untreated cells, ${ }^{*} \mathrm{P}<0.05$ and \#\#\#<0.001 compared with cells treated with TNF- $\alpha$ and DCF individually. 
Fig. 6. Western blotting analysis of p-elf2 $\alpha$ in differentiated and undifferentiated HepaRG cells after exposure to DCF \pm TNF- $\alpha$.

Western blots (A) and quantification by densitometry (B) of p-elf2 $\alpha$ content in differentiated and undifferentiated HepaRG cells after $2 \mathrm{~h}$ treatment. Results are expressed relative to the levels found in control cells, arbitrarily set at a value of 1 .

Fig. 7. Effects of inhibitors on caspases 8 and 9 activities in HepaRG cells exposed to DCF \pm TNF- $\alpha$.

NAC, etanercept and z-LEHD-fmk were added individually. A and C correspond to differentiated HepaRG cells and B and D to undifferentiated HepaRG cells. All results are expressed relative to the levels found in control cells, arbitrarily set at a value of 1 . ${ }^{*} P<0.05,{ }^{*} P<0.01$ and ${ }^{* \star *} P<0.001$ compared with untreated cells, ${ }^{\#} P<0.01$ and

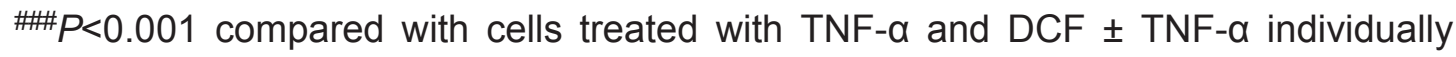
without co-addition of inhibitors.

Fig. 8. Analysis of glutathione transferases (GSTs) in differentiated and undifferentiated HepaRG and HepG2 cells after exposure to DCF \pm TNF- $\alpha$.

Western blots and their quantifications: (A and C) GSTA1/2 and (B and D) M1/2 in differentiated and undifferentiated HepaRG cells and in HepG2 cells. HSC-70 was used as a loading control. ( $E$ and F) measurement of GSTA1/2 and GSTM1/2 genes expression in differentiated HepaRG cells after treatment with DCF \pm TNF- $\alpha$. Results in ( $C$ and $D)$ are expressed relative to the levels found in differentiated HepaRG cells, arbitrarily set at a value of 100 . Results in ( $E$ and F) are expressed relative to the levels found in control cells, arbitrarily set at a value of 1 . ${ }^{\star} P<0.05$, ${ }^{\star *} P<0.01$ and ${ }^{* \star *} P<0.001$ compared with untreated cells, ${ }^{\# \#} P<0.001$ compared with cells treated with TNF- $\alpha$ and $\mathrm{DCF} \pm \mathrm{TNF}-\alpha$ individually without co-addition of inhibitors. 
Fig. 9. Effects of ethacrynic acid on caspase 3 activity in differentiated HepaRG cells.

Cells were treated with DCF $\pm \mathrm{TNF}-\alpha$ in the presence or absence of $10 \mu \mathrm{M}$ ethacrynic acid for $24 \mathrm{~h}$ before determination of caspase 3 activity. All results are expressed relative to the levels found in control cells, arbitrarily set at a value of $1 .{ }^{*} \mathrm{P}<0.05$ and ${ }^{* * *} \mathrm{P}<0.001$ compared with untreated cells, ${ }^{\# \#} \mathrm{P}<0.01$ and ${ }^{\# \#} \mathrm{P}<0.001$ compared with cells treated with TNF- $\alpha$ and DCF individually. ${ }^{\$ P}<0.05$ and ${ }^{\$ \$ P}<0.01$ compared with cells unexposed to ethacrynic acid.

Fig. 10. Effects of DCF $\pm T N F-\alpha$ on bile canaliculi morphology, DCF accumulation and NTCP activity in differentiated HepaRG cells.

(A) Phase-contrast microscopy images showing bile canaliculi and intracanicular accumulation of fluorescent CDF after 4 and $24 \mathrm{~h}$ of treatment (DCF at $200 \mu \mathrm{M})$. (B) NTCP activity after 24h. White arrow shows dilatation of bile canaliculi. Results on NTCP activity are expressed relative to the levels found in control cells, arbitrarily set at a value of $1 .{ }^{* \star *} P<0.001$ compared with untreated cells. 
Figure 1

A

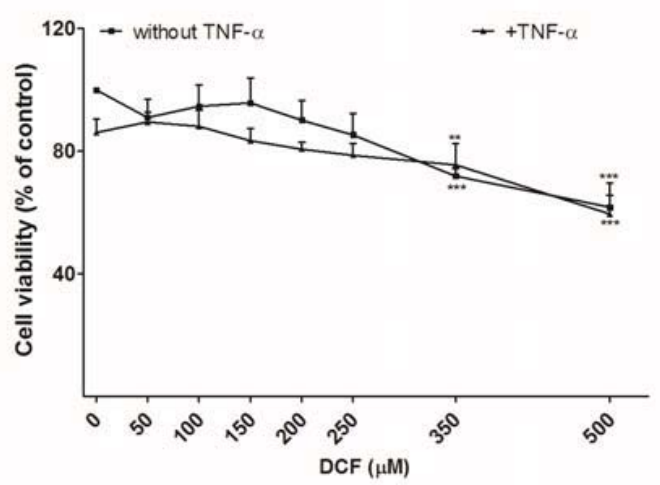

C

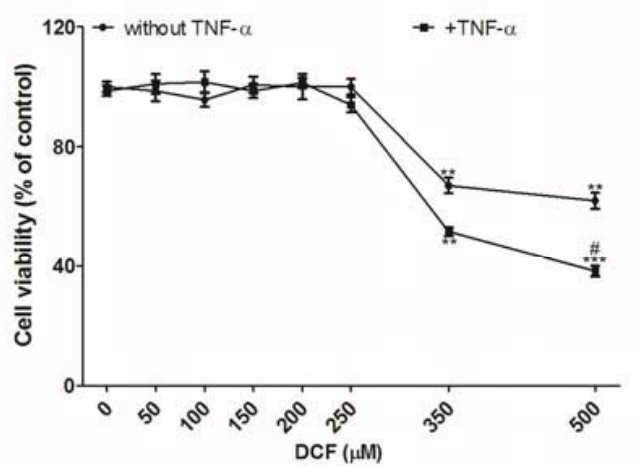

E

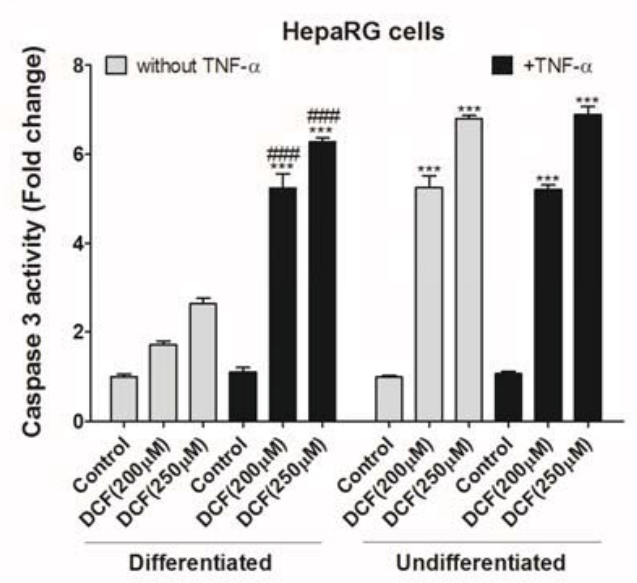

B Undifferentiated HepaRG cells

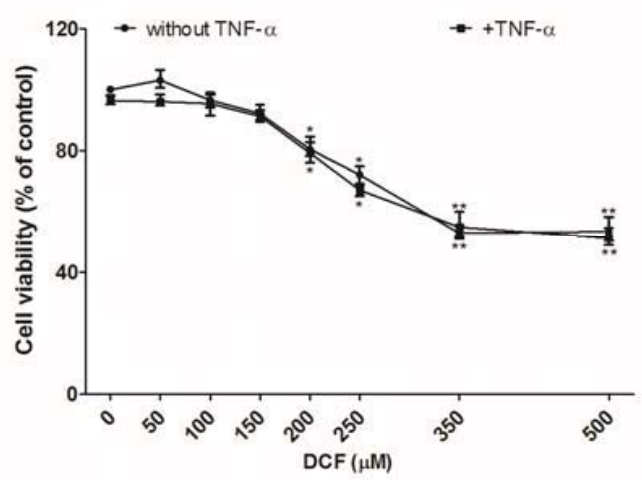

D

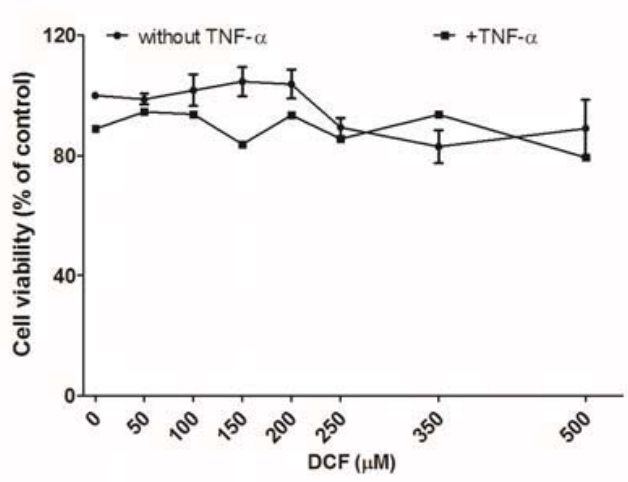

F

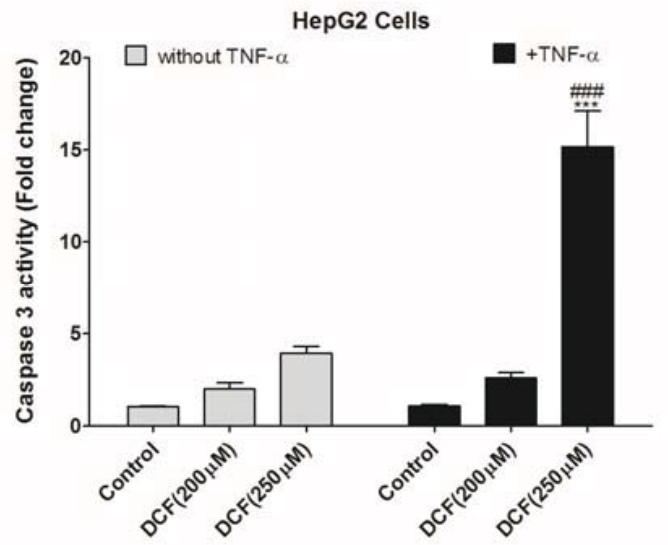


40

Figure 2

Differentiated

HepaRG cells (24h)
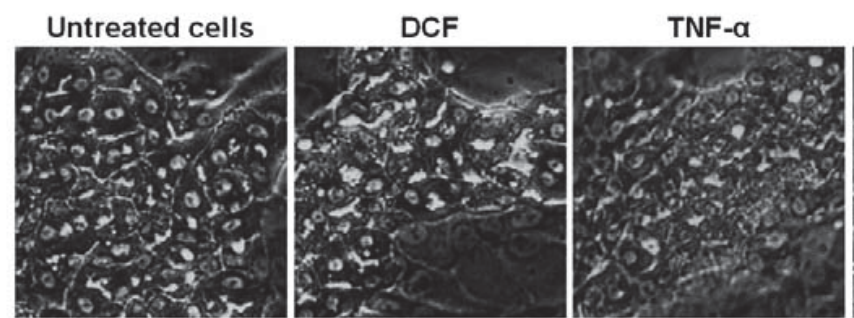

DCF + TNF-a

Undifferentiated

HepaRG cells (24h)
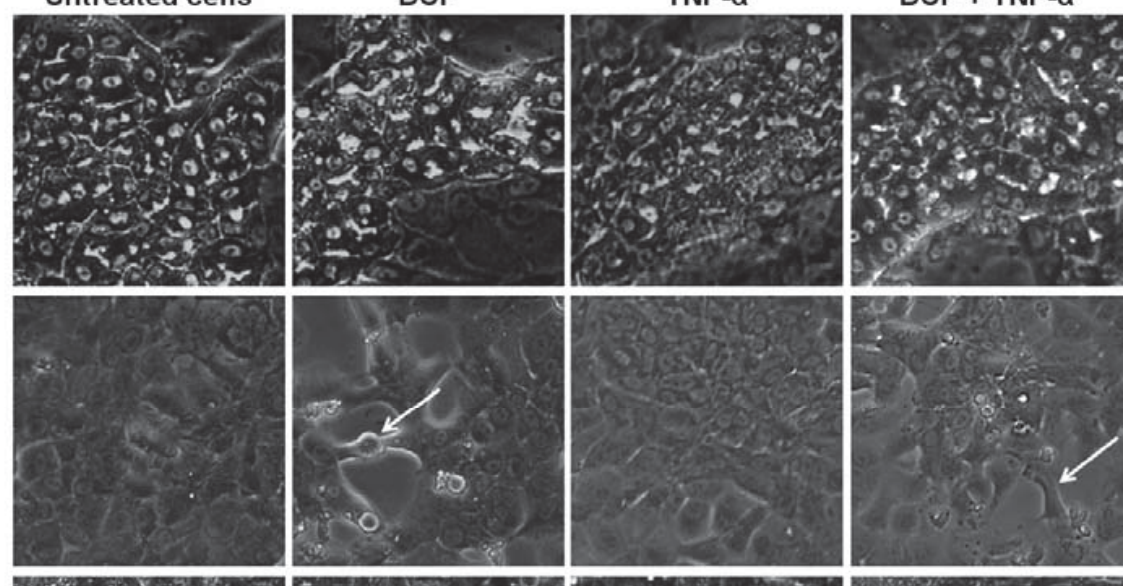

HepG2 cells (24h)
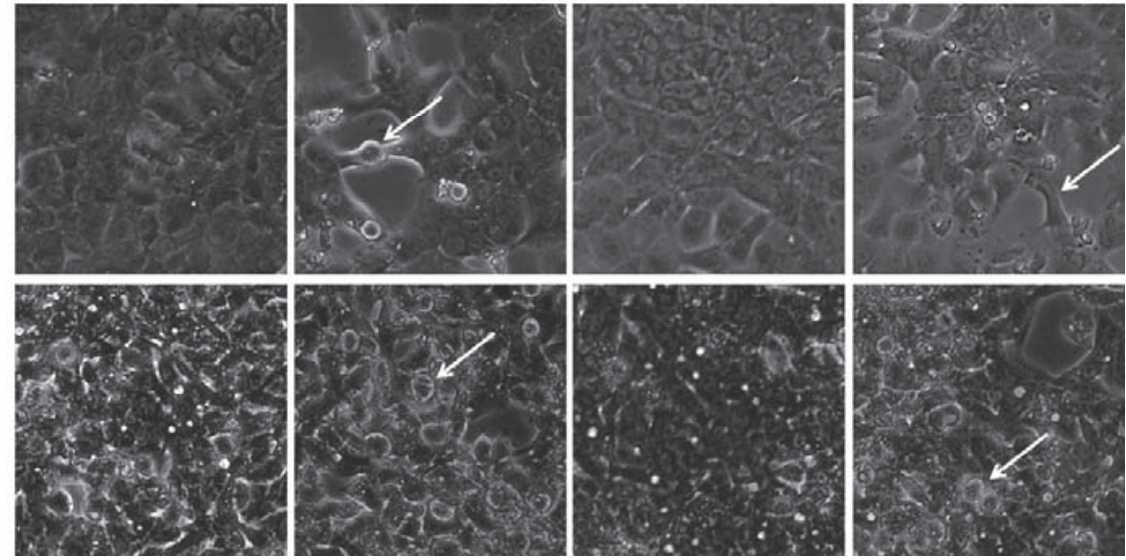
Figure 3

A

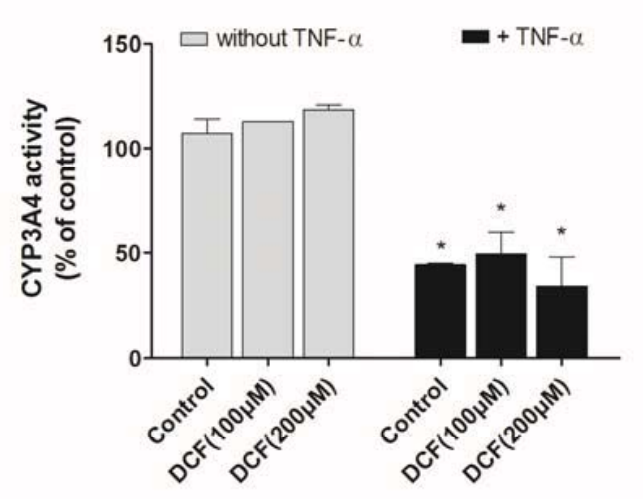

C

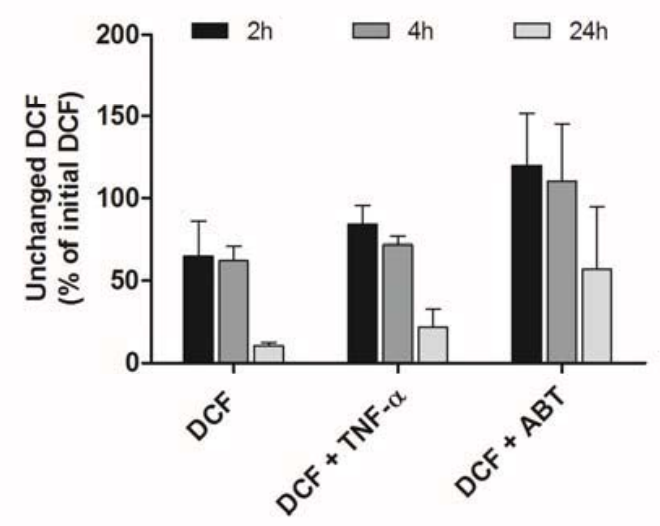

E

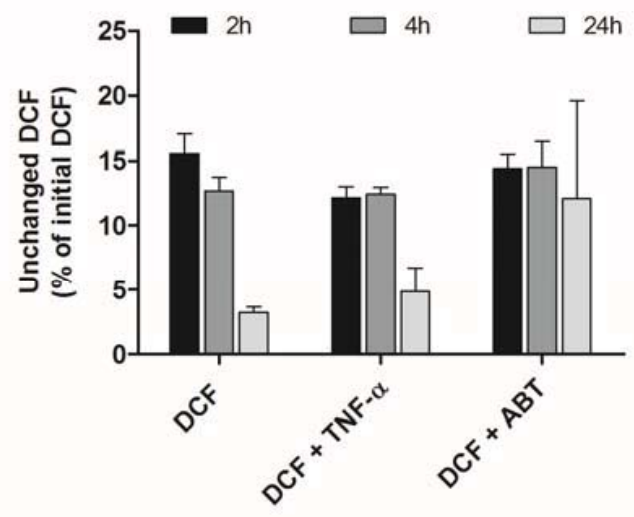

B

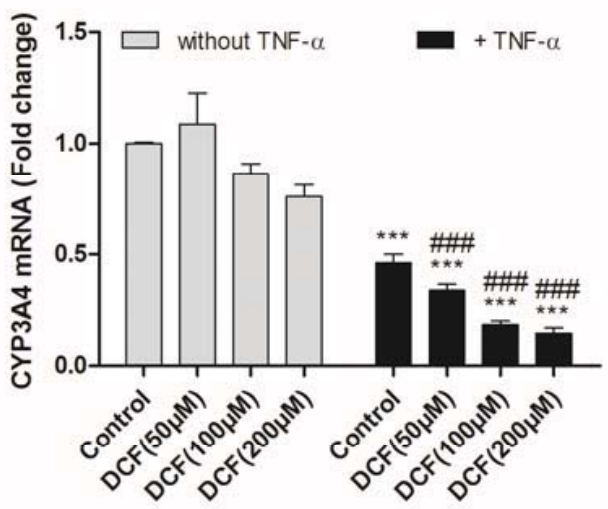

D

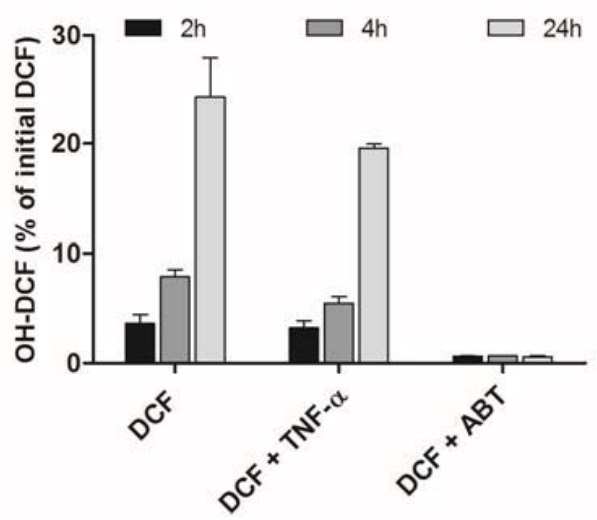

F

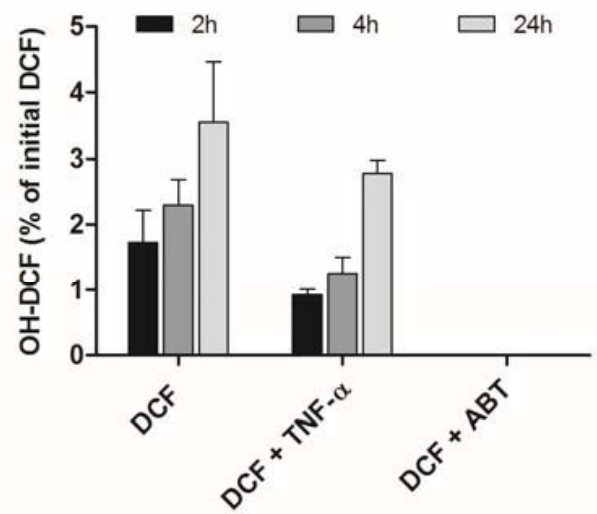


Figure 4
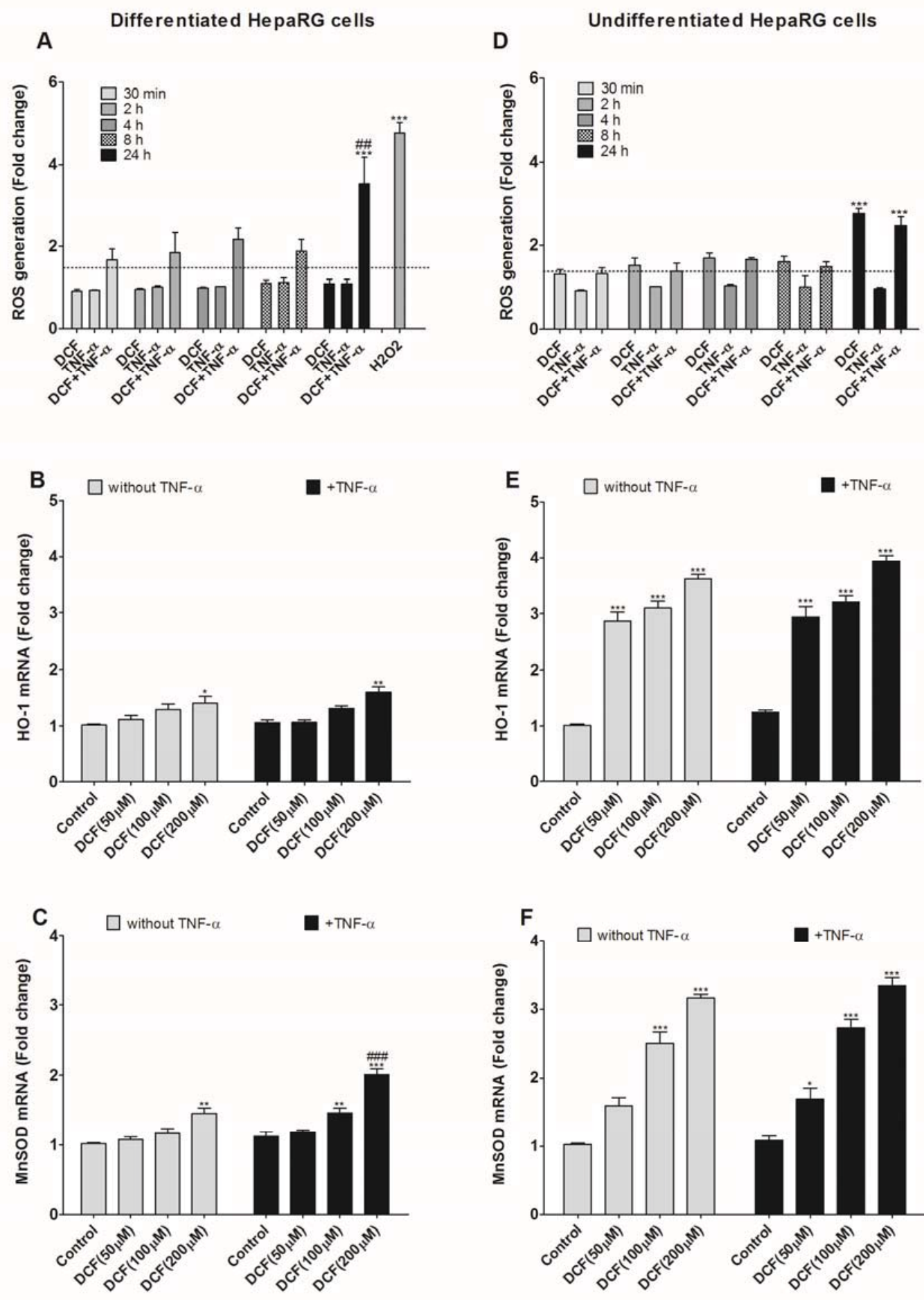
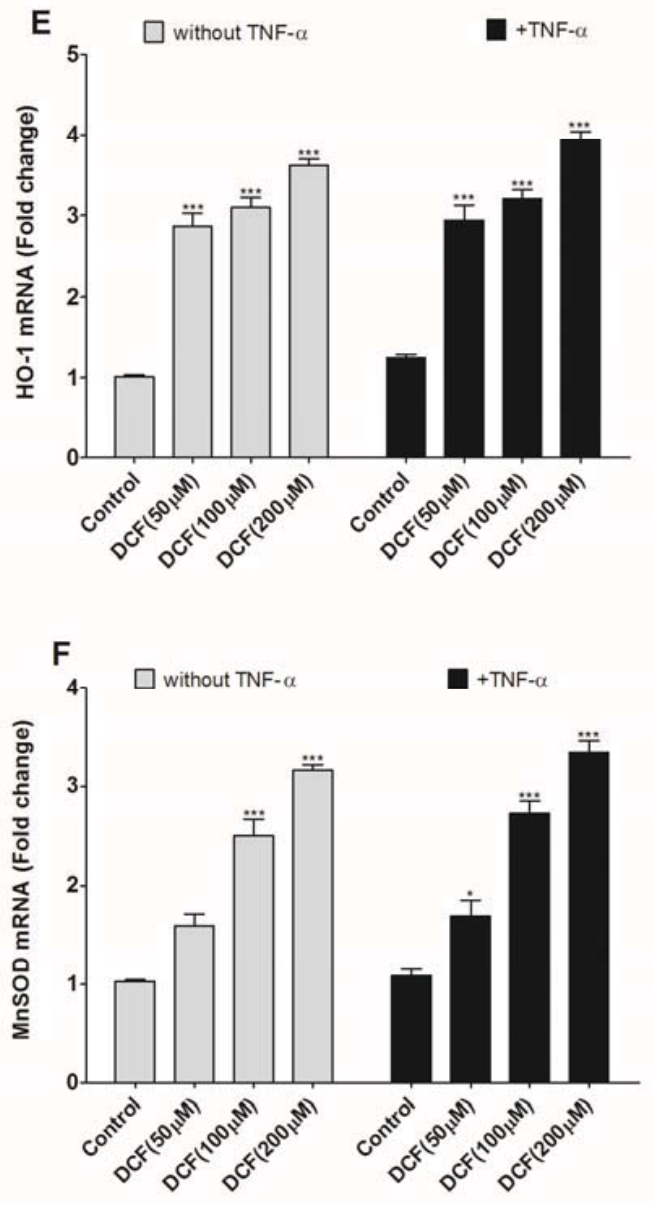
Figure 5

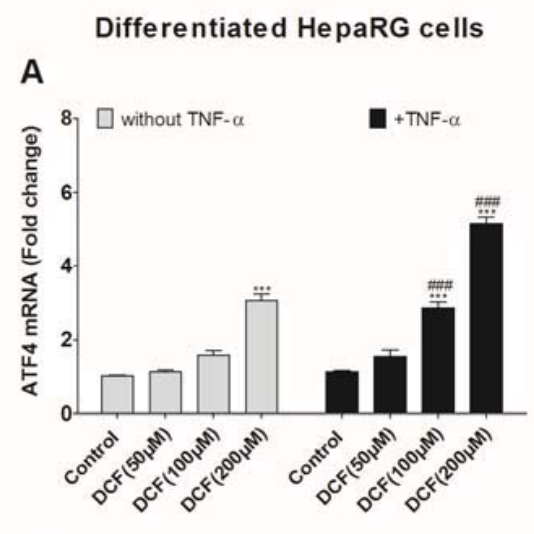

E

Undifferentiated HepaRG cells

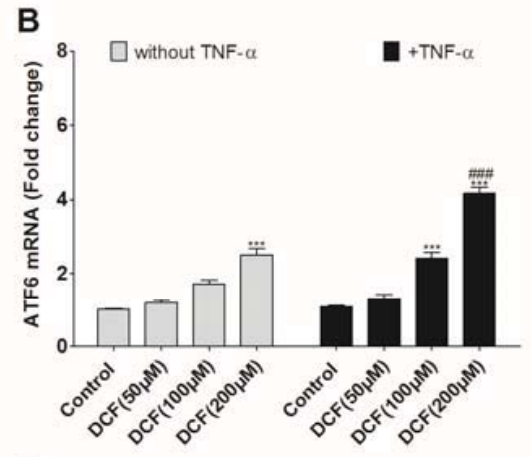

C

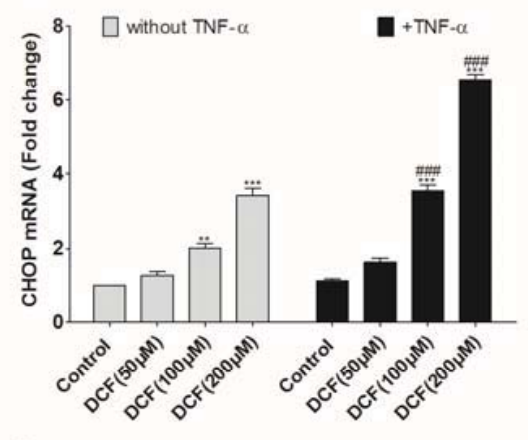

D

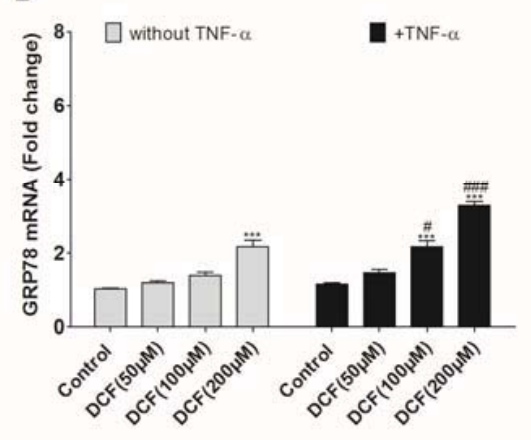

F

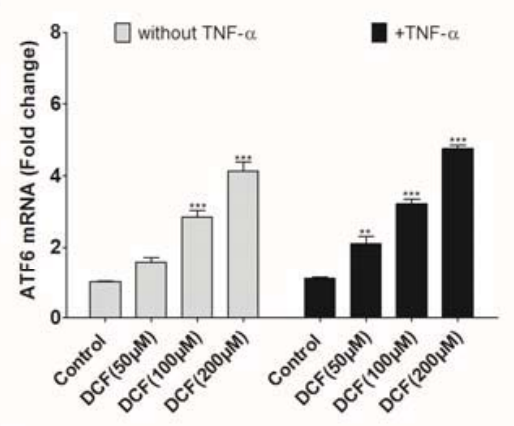

G

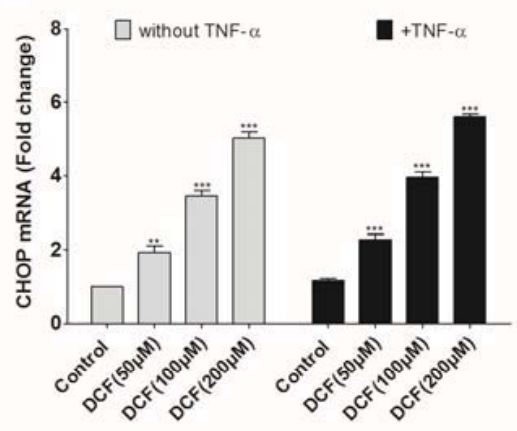

H

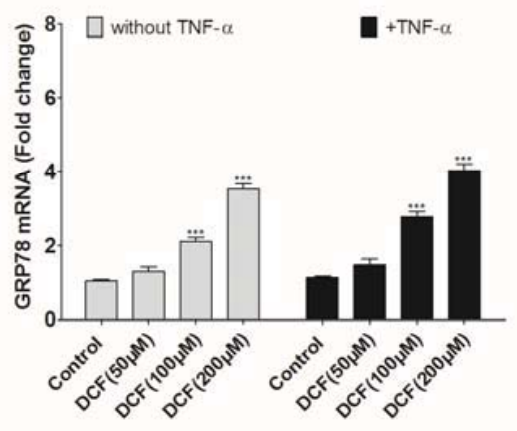


Figure 6
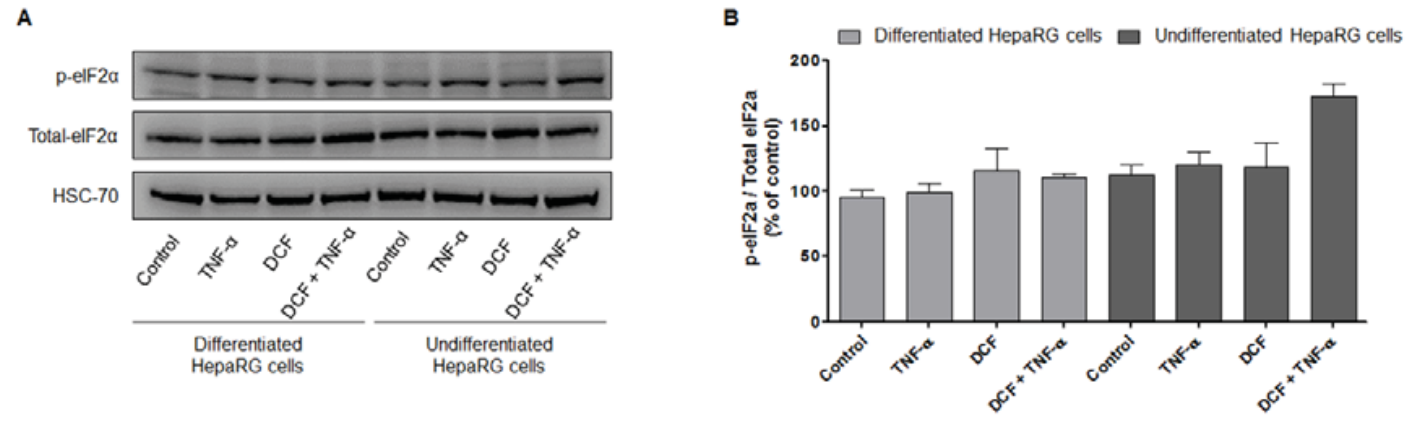
Figure 7

A

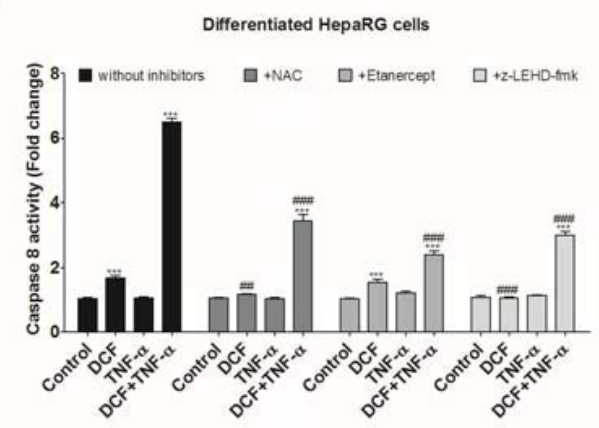

B

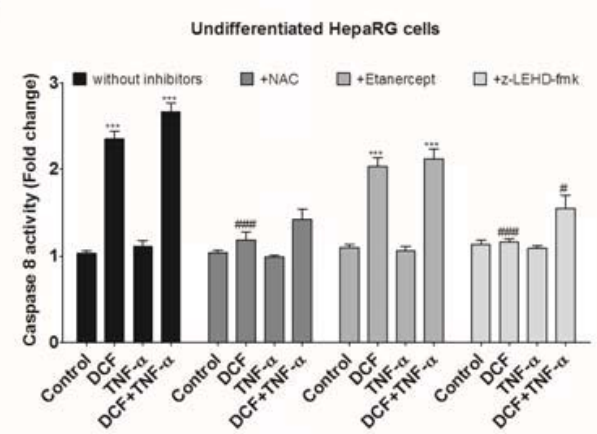

C

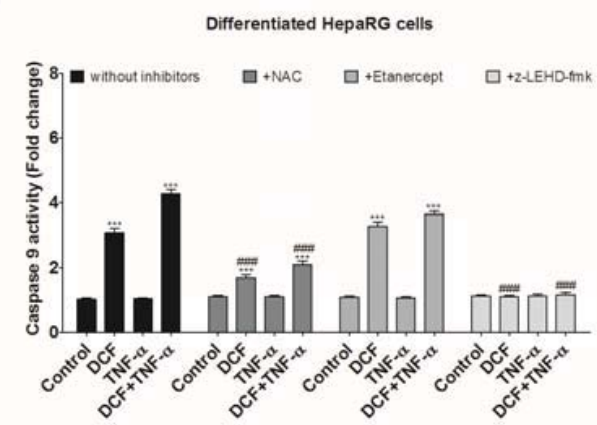

D

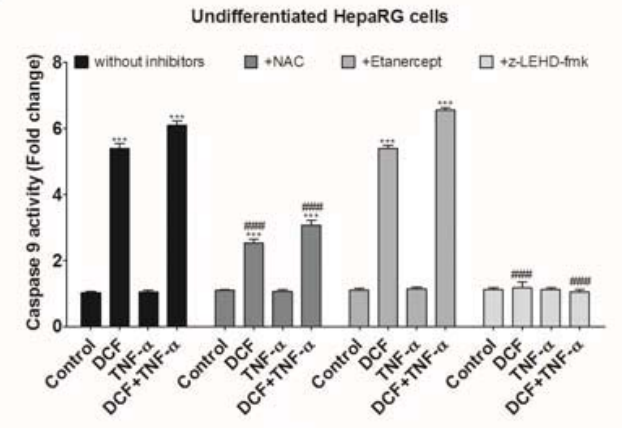


Figure 8

A

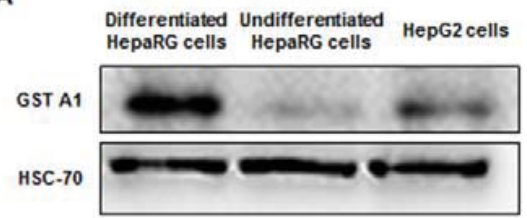

C

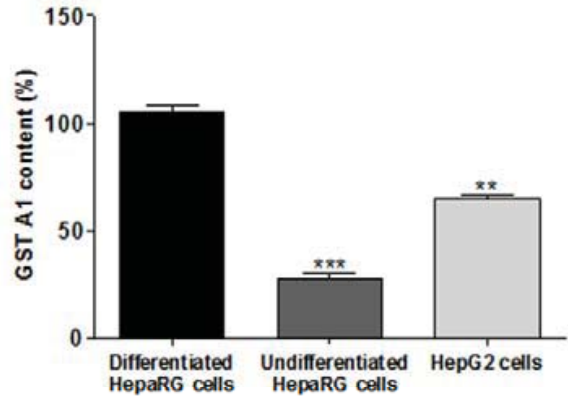

E

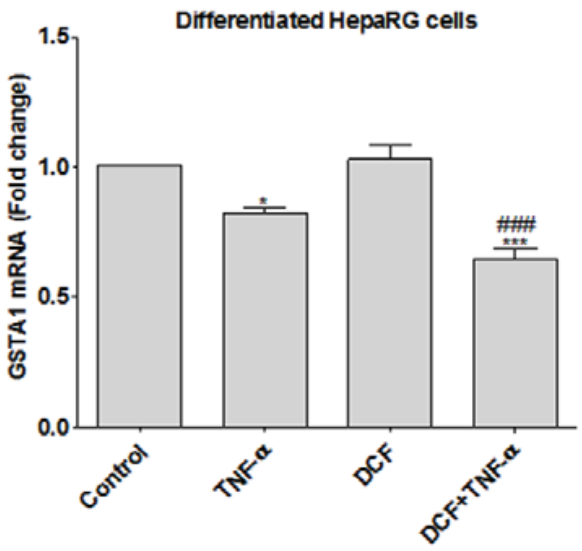

B

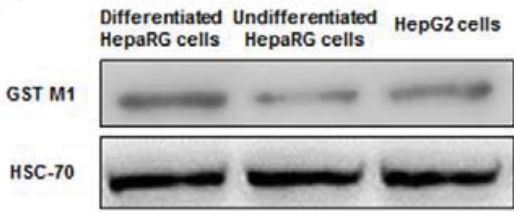

D
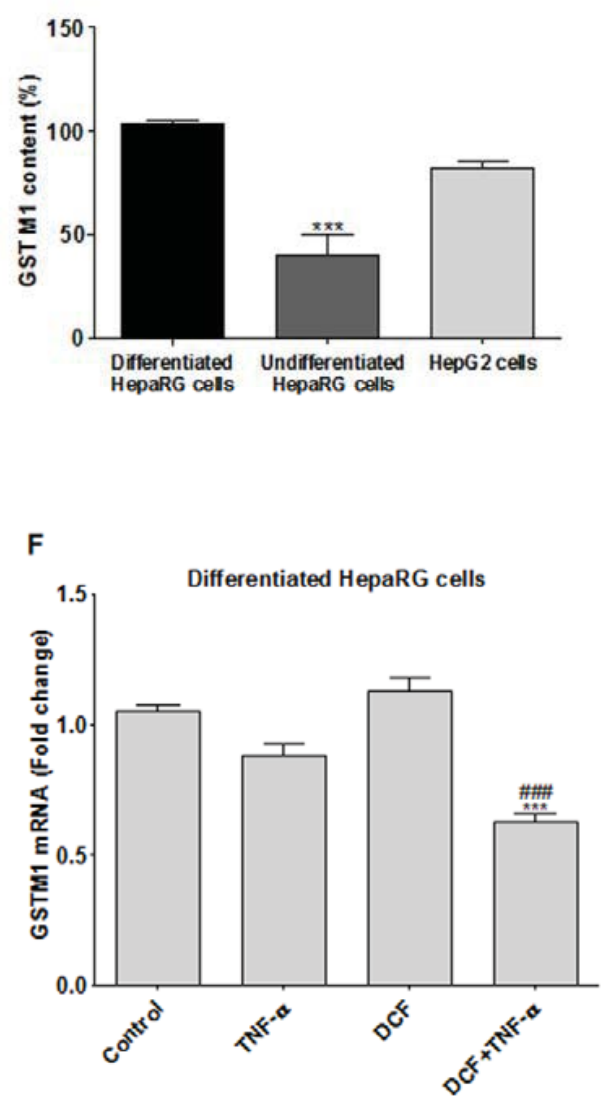
Figure 9

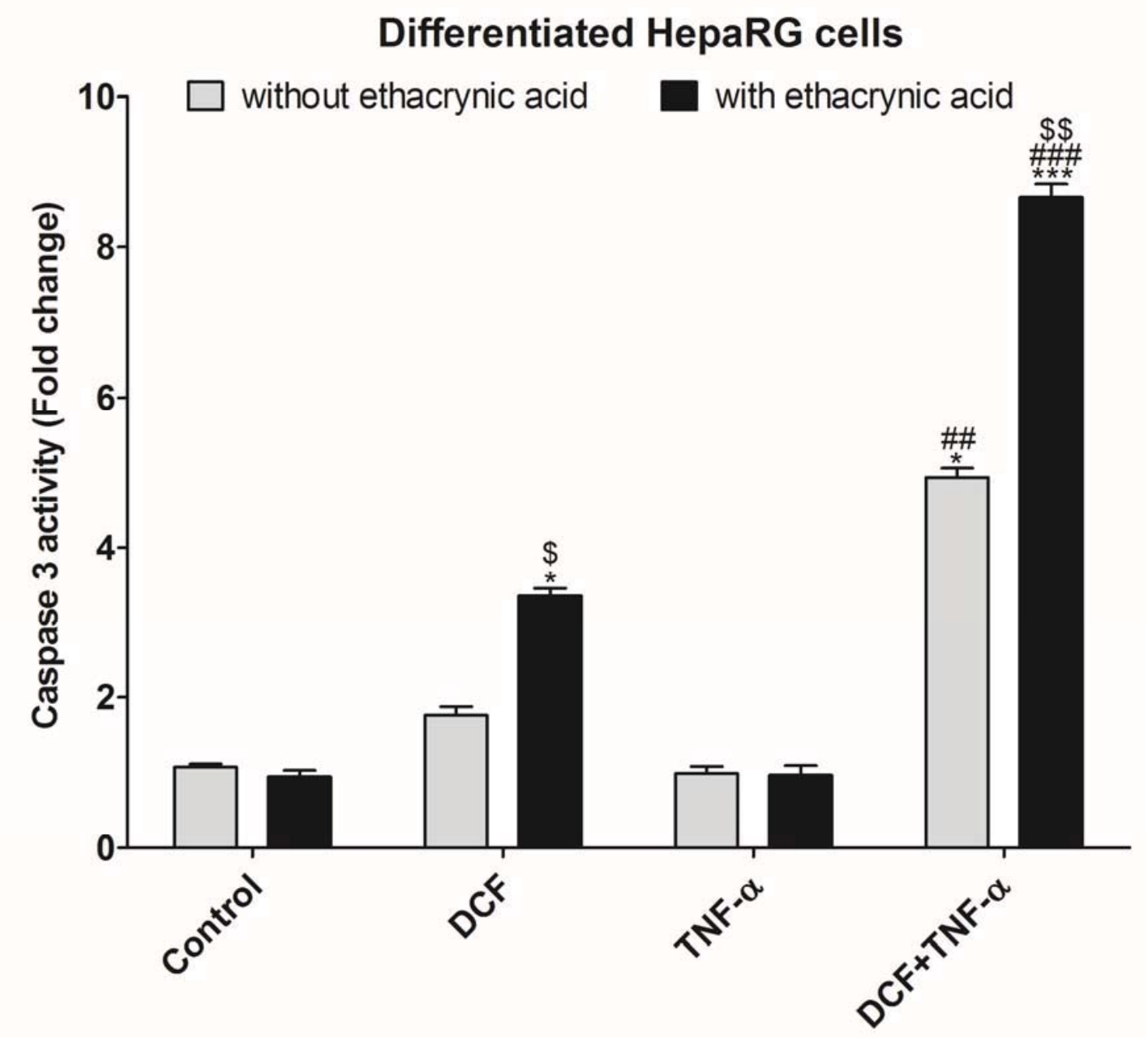


Figure 10

A

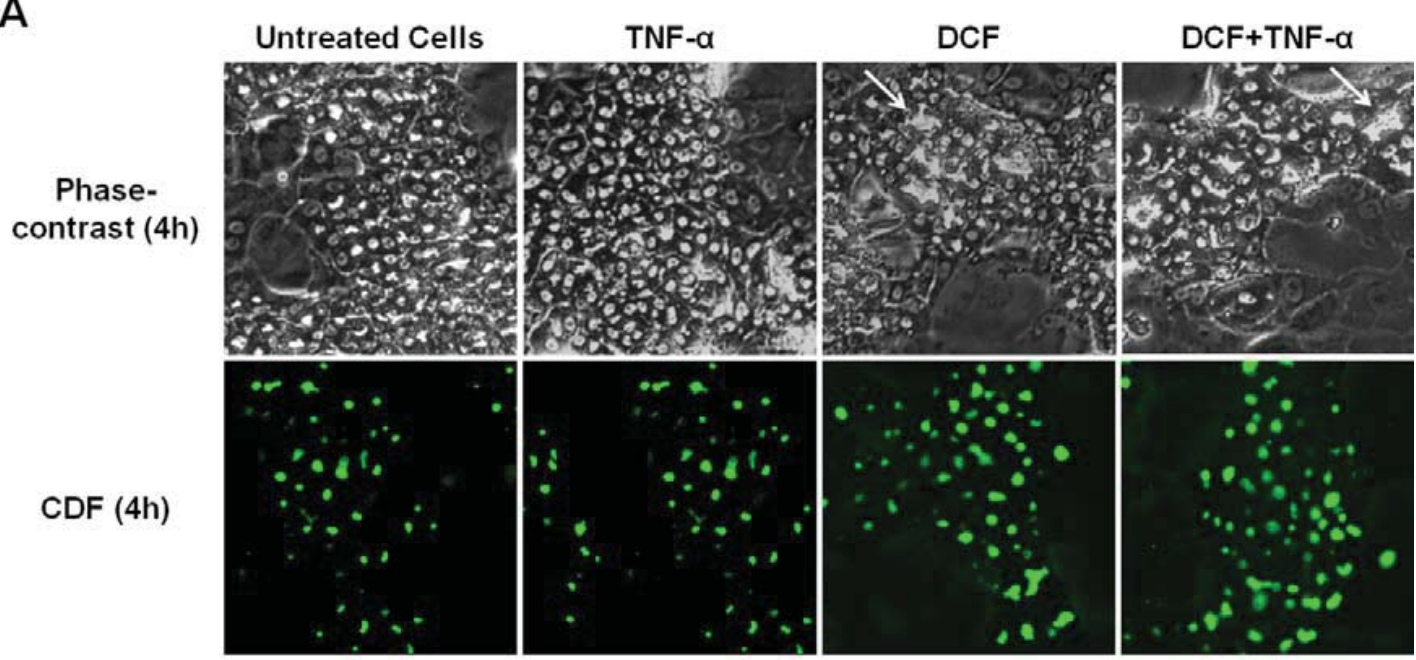

B

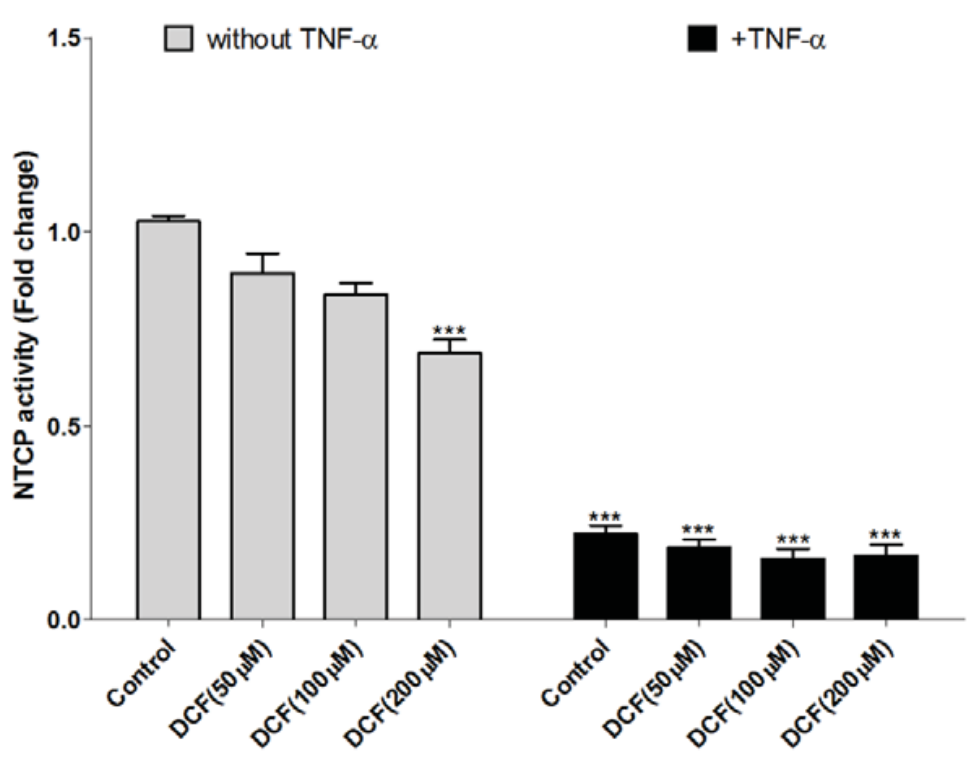

